\title{
The First Five Decades of Cooperation for Development. Actors, Achievements and Challenges ${ }^{1}$
}

\author{
M. Larionova, E. Safonkina
}

\begin{abstract}
Marina Larionova - PhD, Head, Centre for International Institutions Research (CIIR), Russian Presidential Academy of National Economy and Public Administration (RANEPA); Professor, Faculty of World Economy and International Affairs, National Research University Higher School of Economics; 11 Prechistenskaya naberezhnaya, 119034, Moscow, Russian Federation; E-mail: larionova-mv@ranepa.ru
\end{abstract}

Elizaveta Safonkina - Researcher, Centre for International Institutions Research (CIIR), Russian Presidential Academy of National Economy and Public Administration (RANEPA); 11 Prechistenskaya naberezhnaya, 119034, Moscow, Russian Federation; E-mail: safonkina-ea@ranepa.ru

\begin{abstract}
The sustainable development goals (SDGs) adopted in 2015 by the United Nations (UN) in the 2030 Agenda for Sustainable Development collectively serve as a universal guide for developed and developing countries in their national policies and international cooperation aimed at combating global challenges. The SDGs build on the outcomes of the Global Partnership for Development Co-operation (GPEDC), the foundations of which were laid in the 20th century. This article explores the system of international development cooperation as it evolved in the UN from 1946 until the adoption of the UN Millennium Declaration in 2000. It analyzes the resolutions and official records of the main UN bodies, with emphasis on the General Assembly (GA) and the Economic and Social Council (ECOSOC). Content analysis of the records reveals the delegations' positions, interests, contradictions and tensions which may have been concealed by the smooth text of the resolutions.

Four development decades culminated in adoption of the Millennium Declaration. Each stage had its achievements and problems. The main principles, mechanisms and areas of cooperation were molded in early sessions of the GA and ECOSOC. The creation of development support instruments began in mid-1940s, when the World Health Organization (WHO), the United Nations International Children's Emergency Fund (UNICEF), the Food and Agriculture Organization (FAO), the Expanded Programme of Technical Assistance (EPTA) and later the UN Special Fund were established. The dollar monopoly was entrenched. The expansion of international trade and removal of barriers to trade issues gained prominence in UN resolutions in the 1950s. In 1960 the goal of increasing flows of assistance and capital to developing countries to $1 \%$ of the combined national incomes of economically developed countries was set for the first time.

The period from 1961-1970 was marked by the adoption of the Programme for International Development Co-operation - including the First United Nations Development Decade and the World Food Programme (WFP), the establishment of the UN Industrial Development Organization (UNIDO) and the UN Conference on Trade and Development (UNCTAD), and by the elaboration of the international development strategy for the second development decade. The need for international monetary reform was debated in conjunction with the UN's pursuit of a solution to the problems of rising debt and international liquidity.

The key milestones of the second decade include the gradual integration of development and environment issues, efforts to resolve the international monetary crisis and alleviate the rising debt burden, an increase of pledged targets for the UN Development Programme (UNDP), the WFP and Special Fund, the decision on the Charter of Economic Rights and Duties of States, efforts to implement the differential treatment principle with regard to developing countries within the General Agreement on Tariffs and Trade (GATT), adoption of the International Development Strategy for the Third United Nations Development Decade, and a failed attempt to launch "global
\end{abstract}

${ }^{1}$ The editorial board received the article in August 2018.

This research was carried out with the financial support of the Russian Humanities Research Foundation within the framework of a research project entitled "Evolution of Multilateral Development Cooperation under the Auspices of the United Nations: from Development Decade to Sustainable Development Goals (SDGs)," project № 18-014-00008. 
negotiations on restructuring of international economic relations on the basis of the principles of justice and equality in order to provide for steady economic development."

In the third decade, progress was made toward strengthening the science and technology capacity as well as the industrial and resource development capacity of developing countries. The UN endorsed the Global Strategy for Health for All by the Year 2000, adopted the Declaration on the Right to Development and the International Development Strategy for the Fourth United Nations Development Decade. The transition to a sustainable development model was a major achievement. The economic recession, high rates of interest, inflation and mounting deficits, the problems of liquidity and balance of payments, protectionism and structural imbalances in the world economy required a comprehensive decision on the reform of the international monetary system. However, global negotiations were deadlocked due to the position taken by the Group of $7(G 7)$ that the independence of the specialized agencies such as the International Monetary Fund (IMF), the World Bank (WB) and the World Trade Organization (WTO) should be guaranteed. Despite efforts by the Group of 77 (G77) to deal comprehensively with the full range of economic issues, the G7's insistence on the 1982 Versailles summit formula blocked global negotiations, defining the system's rigidity for many years to come and contributing to its failure to prevent the 1998 and 2008 crises.

The Agenda for Development adopted in June 1997 and the UN Millennium Declaration adopted in September 2000 became the landmarks of the fourth decade and development cooperation history.

The international community came a long way in building and consolidating development cooperation in the second half of the 20th century. The UN became a cradle and a driver of this process and was a factor in its success. Indisputable achievements resulting from collective efforts over 55 years include a consistent consolidation of its foundational programme documents from the first development decade to the Millennium Development Goals (MGDs), continuous improvement of the review and appraisal process, integration of environmental issues into the development agenda, establishment of key development cooperation institutions and a significant increase in financing for development. However, efforts to create the conditions for sustained progress and development restructuring of the international economic system taking account of the interests of developing countries failed. The 21st century inherited the systemic problems of the international monetary and trade systems.

Key words: cooperation for development; United Nations; General Assembly; ECOSOC; UNDP; international financial institutions

For citation: Larionova M., Safonkina E. (2018) The First Five Decades of Cooperation for Development. Actors, Achievements and Challenges. International Organisations Research Journal, vol. 13, no 4, pp. 96-136 (in English). DOI: 10.17323/1996-7845-2018-04-05.

The United Nations (UN) sustainable development goals (SDGs) established in the 2030 Agenda for Sustainable Development adopted in 2015 collectively serve as a universal guide for developed and developing countries in their national policies and international cooperation aimed at meeting global challenges. The SDGs build on the outcomes of the Global Partnership for Development Co-operation (GPEDC), the foundations of which were laid in the 20th century. This article explores the system of international development cooperation ${ }^{2}$ as it evolved in the UN from 1946 until the adoption of the UN Millennium Declaration in 2000.

\section{Methodology}

This study analyzes the resolutions and official records of the UN's main bodies, and especially of the General Assembly (GA) and the Economic and Social Council (ECOSOC). Content analysis reveals the delegations' official positions, interests, contradictions and tensions which may have been concealed by the smooth text of the resolutions. In this quantitative analysis, all

${ }^{2}$ Development cooperation is understood as an activity that aims explicitly to support national or international development priorities which is not driven by profit, which discriminates in favour of developing countries and which is based on cooperative relationships that seek to enhance developing country ownership. See J. Alonso and J. Glennie [2015]. 
resolutions on cooperation for development have been integrated into a special database and sorted by session and area. ${ }^{3}$ In total, 9,713 GA resolutions and 3,774 ECOSOC resolutions were included in the database; of these 1,010 and 576 were on development, respectively.

Nine categories of documents have been identified:

1. Basic programme documents, including declarations, strategies and charters.

2. Trade policy and development issues. This includes four sets of resolutions. First, documents on trade expansion in developed and developing countries, the rejection of protectionism and the creation of preferential terms of trade for developing countries. Second, resolutions on multilateral trade negotiations. Third, resolutions condemning the use of sanctions and other restrictive measures against developing countries. Fourth, specific issues such as inflation effects on the prices of goods important to developing countries.

3. Development financing issues, including official development assistance, debt relief and the role of international financial institutions such as the International Monetary Fund (IMF), the World Bank (WB) and regional development banks (RDBs).

4. Sectoral development. This category includes resolutions related to sectors such as agriculture and food, industry, science and technology, education and health care.

5. Special needs of individual countries, including least-developed countries, small island states and landlocked countries.

6. Organizational and operational issues, including reports on UN operations, the work of special UN programmes, decisions to strengthen coordination between specialized agencies and resolutions on the establishment of governing bodies.

7. Creation of UN instruments (special funds, regional commissions, etc.).

8. Disarmament and development.

9. Special development issues (the role of women in development, UN volunteers, etc.).

The parameters for the quantitative analysis include the number of resolutions, the share in the total number, the number and share of resolutions in individual categories and the dynamics over years and decades.

\section{A Good Start is Half the Battle? 1946-1960s}

Although the resolution on the first development decade was adopted only in 1961, the GA and the ECOSOC had been shaping the basic principles, mechanisms and areas of cooperation from their first sessions.

During this period, the World Health Organization (WHO), the United Nations International Children's Emergency Fund (UNICEF), the Food and Agriculture Organization (FAO), the International Finance Corporation, the Expanded Programme of Technical Assistance (EPTA), regional economic commissions and the UN Special Fund were established.

In the resolutions and decisions of the first session, devoted mainly to the UN's institutional development, issues of direct relevance to economic and social development featured prominently. Thus, six out of 68 resolutions were devoted to the establishment (activities) of specialized organizations, including the WHO, the International Organization for Refugees and UNICEF. A resolution entitled "Agreements with Specialized Agencies" laid the foundation for cooperation with specialized organizations [UN, 1946]. The GA also discussed and unanimously adopted resolutions on the economic rehabilitation of devastated regions and on overcoming food shortages. Five out of 79 resolutions of the GA's second session approved the

${ }^{3}$ Documents were considered as resolutions on development cooperation if, in one way or another, they contributed to the formation of a collective system: principles, goals, mechanisms or instruments. Resolutions on assistance to specific countries were not included in the database and were not counted in statistics. 
activities of specialized organizations (WHO, UNICEF) and the principles of coordination and cooperation with them [UN, 1947a]. The GA also endorsed the work of the ECOSOC ${ }^{4}$ on the preparation of annual reports on global economic conditions and trends [UN, 1947b], calling for recommendations to improve living standards, ensure full employment and create conditions for economic and social progress and development [UN, 1947c]. However, development assistance and development cooperation issues were not discussed at either of the first two sessions.

Issues of economic assistance to underdeveloped countries were included in the GA's agenda for the first time at the third session, which adopted resolutions on economic development of underdeveloped countries [UN, 1948a] and technical assistance for economic development [UN, 1948b]. Having supported ECOSOC's Resolution 167 on facilitating the loan process of the International Bank for Reconstruction and Development (IBRD), the GA created a time bomb: debt began to accumulate very quickly and even by the 1960 s debt relief issues became critical, along with the search for sources of development financing. Issues of assistance to underdeveloped countries were discussed at almost all subsequent sessions up to 1960, including not only the expansion of technical assistance, but also practical aspects of mobilizing public and private capital to finance non-self-financing projects that were crucial for economic development [UN, 1950].

The amount of funding in the first years was not significant. Funds allocated to the organizations participating in the EPTA by the Technical Assistance Committee for 1956 amounted to $\$ 29,734,085$ [UN, 1955]. The majority of funding was provided to the FAO $(\$ 8,057,000)$, the UN Technical Assistance Administration $(\$ 6,434,852)$, the WHO $(\$ 5,689,280)$ and the UN Educational, Scientific and Cultural Organization (UNESCO) $(\$ 4,940,933)$. This distribution trend persisted in subsequent years. Until the late 1950s, the financing of the EPTA grew insignificantly, reaching the equivalent of $\$ 32,241,079$ in 1960 [UN, 1959a]. The same year, $\$ 150$ million [UN, 1960a] was announced as a funding target of the Special Fund and EPTA, and for the first time an objective was set to increase the provision of international assistance and capital to $1 \%$ of the national income of advanced economies as soon as possible [UN, 1960b].

In the late 1940s, the process of creating development assistance instruments began. Decisions were often preceded by heated discussions. For example, 16 countries, including Canada, Australia, New Zealand, the United Kingdom, the United States, France, the Netherlands, Belgium, Sweden, and Denmark [UN, 1952a], opposed the creation of a special fund for subsidies and long-term low-interest loans to underdeveloped countries, arguing that contributions from countries that voted against the resolution made up $78 \%$ of the UN budget and $90 \%$ of the budget of the EPTA, while remaining silent about their clear preference to channel aid flows through the IMF and the IBRD. Developing countries, the initiators of the resolution, insisted that the IBRD's lending policy did not allow underdeveloped low-income countries to get loans as they had limited resources to service the debts [UN, 1952b, pp. 331-338]. The preferences of major donors to mobilize private capital for investment in less-developed countries without using government guarantees were reflected in the resolutions of the eighth and ninth sessions of the GA ("On Creating an IFC for Economic Development" [UN, 1953] and "Question of the Establishment of an IFC" [UN, 1954a], respectively).

The path from the decision to create development assistance instruments to their implementation was long and not always successful, since the operational activities of the established structures ultimately depended on voluntary contributions. The decision to establish the UN

${ }^{4}$ According to Article 62 of the charter, the ECOSOC should "initiate studies and reports with respect to international economic, social, cultural, educational, health, and related matters and may make recommendations with respect to any such matters to the General Assembly to the Members of the United Nations, and to the specialized agencies concerned." 
Special Fund for Economic Development [UN, 1954b] was made in 1954 at the ninth session. After a lengthy study, a resolution was adopted at the 12th session to create the fund no later than 1 January 1959 to help implement projects relevant to countries' economic development. The financial resources of the Special Fund amounted to $\$ 100$ million a year, to be received mainly from annual voluntary contributions which were to be specified several years in advance [UN, 1957a]. However, behind this smooth formulation were significant differences between the members of the preparatory committee ${ }^{5}$ regarding the objectives of the fund, its modalities and the amount of funding. The initial idea (of France) was that technical assistance should be provided to underdeveloped countries through an appropriate programme. National and international banking institutions would finance profitable operations, and the new fund would be designed to finance unprofitable projects necessary for further economic development. The USSR believed that "the Special Fund should provide credit facilities and should grant the underdeveloped countries low-interest or interest-free loans and subsidies, but it should not disburse all the contributions and funds it receives, as would a charitable organization. It is only in this way that the Special Fund can increase its capital and expand its operations, ultimately raising them to the levels required to meet the vast needs of the economic development of the underdeveloped countries" [UN, 1957b, p. 811]. The proposal made at the GA session on the use of the fund for capital development was forcefully rejected by the United States. The U.S. argued that the fund's resources were insufficient, since in order to support capital development, "financial support in the neighborhood of 400 or 500 million dollars in generally usable currencies should be available on an annual basis... in addition to the sums provided for United Nations programmes of technical assistance" [p. 813].

At the thirteenth session, the GA adopted a resolution establishing the Special Fund, but not the Fund for Economic Development. It was stated that contributions should be made in currencies readily usable by the Special Fund, consistent with the principles of efficiency and economy, or in currencies transferable to the greatest possible extent into a currency readily usable by the fund [UN, 1958a]. The USSR voted for the draft resolution, but considered it an "interim measure pending the establishment of a really universal fund for the economic development of underdeveloped countries, of transforming the Special Fund into SUNFED, i.e., into a fund for the financing of the economic and industrial development of under-developed countries and therefore a fund with much wider aims and terms of reference" [UN, 1958b, pp. 504-5]. This was the position shared by developing countries and socialist states. The GA endorsed the report and unanimously approved the start of the Special Fund's operations at the 14th session [UN, 1959b], and in 1965 the decision was made to consolidate the Special Fund and the EPTA into a UN Development Program (UNDP) [UN, 1965a]. The question of the UN Capital Development Fund, established by the GA's policy decision in 1960 [UN, 1960c], remained on the GA and ECOSOC agendas for a long time, but it has never become an effective instrument for development financing. In 1967, the fund was essentially integrated into the UNDP and the administrator of the UNDP was entrusted with administering the fund by performing the functions of the managing director, while the governing council of the Programme assumed the functions of the executive board of the fund. It was decided that the pledging conference on the fund would be convened simultaneously with the pledging conference on the UNDP [UN, 1967].

At the first stage of the establishment of development cooperation instruments, the dollar monopoly became entrenched. The wording on making contributions in convertible currencies has been included in most resolutions on budgeting. The debate at the 11th session [UN, 1956a] on a U.S.-initiated resolution on the use of currencies was illustrative [UN, 1956b]. The

${ }^{5}$ Ghana, Denmark, Egypt, India, Canada, Mexico, the Netherlands, Pakistan, Peru, the United Kingdom, the United States, the Union of Soviet Socialist Republics, France, Chile, Yugoslavia and Japan. 
document proposed the use of convertible currencies if states provided financing in excess of $\$ 500,000$. The USSR opposed a resolution "undermining the principle of voluntary contributions by the member states to the programme for financing technical assistance to underdeveloped countries." The USSR's representative declared: "In the opinion of the Soviet delegation, contributions to the United Nations programme of technical assistance should, at the discretion of each country, be made in national currencies, on a voluntary basis and without any limitations whatever. The Soviet delegation wishes to make it quite clear that it is opposed to any limit being placed on the amount that countries can contribute to the United Nations technical assistance programme in national currencies. It opposes any limitation or discrimination with regard to the individual currencies of other States Members of the United Nations. The United Nations should not give any preferential treatment to individual currencies, including the United States dollar. The Soviet Union has adequate means, considerable industrial and technical experience and duly qualified experts enabling it to provide under-developed countries with effective and beneficial technical assistance in the full amount of its contribution and in any form consistent with the principles of the United Nations. The Soviet rouble is one of the most stable and readily usable currencies in the world for purposes of providing technical assistance." [UN, 1956a] However, with 64 votes in favour, 7 against and 2 abstentions, a draft resolution was adopted to refer the records of the debate to the ECOSOC and the Technical Assistance Committee to consider the issue at the 24th ECOSOC session, where the use of convertible currencies was approved.

An integrated approach and the principle of creating both internal and external conditions for development were established during the first decade of cooperation. For example, the resolution on the industrialization of underdeveloped countries included taxation issues (avoidance of double taxation) to attract private capital, as well as the question of an integrated and coordinated approach to industrialization and labour productivity [UN, 1957c]. The role of international economic and trade policy in development became the subject of debate for the first time at the fourth session of the GA, where it was recommended that the ECOSOC take into account the influence of policy measures on the economic development of underdeveloped countries when making recommendations to the GA [UN, 1949]. The resolution "Development of International Economic Cooperation and the Expansion of International Trade" emphasized the role of trade in economic development, the need to reduce barriers, expand trade and approve an agreement establishing the organization for trade cooperation [UN, 1957d].

At the end of the decade, issues related to the development of the world market and the improvement of trade conditions for development occupied an increasingly important place in development resolutions [UN, 1959c], including measures aimed at combating price fluctuations in commodity markets [UN, 1959d], expanding markets and facilitating access of commodities of underdeveloped countries to the markets of developed countries [UN, 1960d] and increasing the share of their products in international trade [UN, 1960e]. At the same time, decisions were taken that created the risk of market price fluctuations and barriers to the sale of agricultural products of developing countries [UN, 1960f]. This was the case, for example, with a resolution adopted at the suggestion of the U.S. and Canada on the provision of food surpluses to food-deficient peoples through the UN system [UN, 1960g]. The efforts of a number of developing countries to create an international trade organization were ignored or faced polite resistance from the members of the General Agreement on Tariffs and Trade (GATT) ${ }^{6}$

In general, despite the difficulties of establishment, in the early years the foundation was laid for future cooperation: specialized institutions, funds, programmes and coordination

${ }^{6}$ The USSR did not take part in the creation of the International Trade Organization (ITO) during the development of its charter, which was completed at the conference in Havana (November 1947-March 1948). 
mechanisms were created, and priorities for creating internal and external conditions for development were identified, including the expansion of international trade and financing for industrial and agricultural development. For the first time, an objective was formulated to increase the volume of international assistance and capital provision to $1 \%$ of the national income of economically developed countries.

\section{The First United Nations Development Decade, 1961-1970}

The period from 1961-1970 was marked by the adoption of the programme for international economic cooperation - the United Nations Development Decade and the World Food Programme (WFP), the establishment of the UN Industrial Development Organization (UNIDO), the UN Conference on Trade and Development (UNCTAD) and the UNDP, the adoption of the International Development Strategy for the Second United Nations Development Decade, and efforts to reform the international monetary system. These are only some of the milestones in the evolution of development cooperation during this period.

The First United Nations Development Decade's key programme document [UN, 1961a] identified measures "required on the part of both developed and developing countries to accelerate progress toward self-sustaining growth and of the economy of the individual nations and their social advancement...with each country setting its own target, taking as the objective a minimum annual rate of growth of aggregate national income of 5\% at the end of the Decade." These measures included assistance in industrialization, creation of a highly productive agricultural sector, mobilization of domestic resources, elimination of hunger and disease, development of education and vocational training, and research activities. The GA called on member states to provide market access for products from developing countries, to carry out activities aimed at providing developing countries with an equitable share of earnings from the extraction and marketing of their natural resources by foreign capital, and to take measures aimed at stimulating the inflow of private investment capital on terms satisfactory both to the capitalexporting and capital-importing countries. At the same time, the goal of accelerated capital inflows and technical assistance to developing countries was reiterated in order for these indicators to achieve $1 \%$ of the total national income of economically developed countries as soon as possible. Governments and specialized agencies were requested to provide information on the gross and net amount of capital inflows and international assistance to the Secretary-General [UN, 1961b]. The planned financing targets for the Special Fund and the EPTA were gradually increased. And in 1965, the UNDP was created through the merger of the Special Fund and the EPTA [UN, 1965b]. Though it was intended to preserve two funds, the characteristic features of the two programmes and the option to make contributions separately.

To support industrialization and expansion of UN activities in the field of industrial development, the decision was taken to establish a specialized body [UN, 1963a]. The resolution of the 20th session of the GA established the UNIDO as an autonomous organization. It was de-

\footnotetext{
The charter of the ITO was signed by more than 50 states and could enter into force after ratification by a majority of signatories. However, due to the changed position of the United States, the charter did not enter into force. During the preparation for the Havana conference, a group of 23 states held talks on tariff concessions and on 30 October 1947 signed the final act of the first tariff conference, which included the text of the GATT. The participating countries pledged to comply with the general principles of the first to fourth and ninth chapters of the Havana Charter. On 1 January 1948, the Protocol on the Temporary Application of GATT entered into force. In the future, the development of the international trading system was carried out mainly under the influence of the GATT [Shumilov, 2005]. However, in the 1950s, the USSR repeatedly raised the issue of the establishment of the ITO for the development of world trade and overcoming the closure of the GATT, which is "closed and limited...from the point of view both of its composition and its functions" [UN, 1959e, p. 963].
} 
cided that its administrative and research activities would be financed from the regular budget of the UN while its operational activities would be financed by voluntary contributions [UN, 1965c] and by resources from the UN regular programme of technical assistance [UN, 1966a].

The WFP was established on an experimental basis with an expected volume of voluntary contributions of $\$ 100$ million per year. The programme aimed to supplement food aid with support for agricultural sector development [UN, 1961c]. The target for contributions to the programme grew steadily and already by 1969 voluntary contributions for 1971-72 were approved in the amount of $\$ 300$ million, of which at least one third should be in cash and services [UN, 1969a].

Issues of trade as a resource for economic development remained in the spotlight. Trying to correct the effects of the decision on food surpluses, the GA called for the avoidance of steps leading to discrimination and fluctuations in commodity price markets, prevention of adverse market consequences associated with the disposal of surpluses, and convening of a conference on international trade problems, especially relating to commodities [UN, 1961d]. The USSR, which put forward the idea of holding the conference, considered its main goal as being "to work out practical and effective recommendations and measures for the development of trade among all countries of the world without discrimination and artificially created restrictions or obstacles... removal of artificially created obstacles to trade between East and West and to trade among other countries of the world" [UN, 1963b, p. 212]. At the same time it regarded the conference as the first step toward the creation of an international trade organization. The memorandum of the Soviet delegation entitled "Preliminary Considerations Regarding the Main Provisions for an International Trade Organization" outlined the main provisions, principles and objectives of the ITO. The proposal did not find support from GATT members, and as a result, UNCTAD [UN, 1965d] became the key UN body on trade and development. Its functions included promoting international trade, formulating principles and policies regarding international trade and related problems of economic development, facilitating coordination of other UN agencies in the field of international trade, and harmonizing trade and related development policies of governments and regional economic groupings.

In order to improve the efficiency and coordination of the activities within the UN system in pursuit of the UN development decade goals, a general review of programmes and activities of the UN, the specialized agencies, the International Atomic Energy Agency, the UN Children's Fund and other UN institutions and agencies in the economic, social, technical cooperation and related fields was carried out in the middle of the decade [UN, 1966b]. An analysis of the preliminary results from the decade was conducted. In 1966, following the report of the secretary-general on the interim results, a decision was taken on an international development strategy for the 1970s [UN, 1966c]. The same year, the GA instructed the ECOSOC to prepare a draft declaration on social development to define the objectives and the methods and means of achieving them [UN, 1966d] in order to complement economic development programmes with social development measures.

An assessment of the progress made toward the goal that the inflow of external resources to developing countries should reach $1 \%$ of the national income of each developed country showed that the debt-servicing burden in 1965 exceeded by more than half the loans received. Net inflow of aid to developing countries remained almost unchanged from 1961 to 1965 ( $\$ 6,600$ million), and the rapid increase in the debt-servicing burden would completely absorb capital inflows in 15 years [UN, 1966e]. The GA urged developed countries to provide at least $80 \%$ of assistance in the form of grants and loans at interest rates of $3 \%$ or less with a repayment period of 25 years or more, increase the share of untied aid, fulfill the targets set for contribu- 
tions to the UNDP and increase contributions to the International Development Association (IDA) by the end of 1968 [UN, 1966f].

The problems of growing debt and descreasing international liquidity determined the need for a reform of the international monetary system to make it more responsive to the requirements of economic growth of both developed and developing countries [UN, 1966g]. At the 23rd session (1968), the GA approved the decision of the IMF Board of Governors to establish the special drawing rights facility and called on member countries for the early ratification [UN, 1968a]. Welcoming the historic decision of the board of governors on the first allocation of $\$ 9.5$ billion in special drawing rights (SDRs) among the fund participants for a period of three years starting 1 January 1970, the GA invited members to consider the possibility of establishing a link between the allocation of the new reserve asset and the provision of additional financing to developing countries, as well as speeding up consideration of quota adjustments to meet the special needs of developing countries [UN, 1969b].

Most development issues were worked out within the Second Committee of the GA (economic and financial issues). However, development issues were integrated into the work of all committees. The use of resources released as a result of disarmament was discussed by the First Committee (issues of disarmament and international security). The right to development was the focus of the Third Committee (social, cultural and humanitarian issues). One of its achievements was the adoption of the Declaration of Social Progress and Development in 1969 [UN, 1969c]. The declaration emphasized the interdependence of economic and social development, calling for a change in international economic relations, in which equality of opportunity should be as much a prerogative of nations as of individuals within a nation.

In the first development decade, there the tendency to integrate development assistance and environmental issues emerged [UN, 1968b]. During the preparation of the UN Conference on the Human Environment, there was an acute discussion of the alignment of the International Development Strategy for the Second United Nations Development Decade goals to improve and preserve the ecological balance with the financial responsibility in the form of additional assistance to developing countries [UN, 1970a, p. 3]. Canada, France, Japan, Luxembourg, New Zealand, South Africa, the United Kingdom, the United States, Australia and Belgium voted against this provision. It was decided that a second session of the preparatory committee would be held to consider the issue of providing additional funds to developing countries for the protection of the environment [UN, 1970b].

The International Development Strategy for the Second United Nations Development Decade, adopted after a lengthy preparation and taking into account the evaluation of progress of the first decade, did not include environmental conservation in the goals, objectives or policy measures of development cooperation [UN, 1970c]. The declaration stated a sustained improvement in the well-being of everyone and bestowing benefits on all as an ultimate objective. It recorded the key principles: the entire international community bears a common and shared responsibility for economic and social progress while the primary responsibility for the development of developing countries rests upon themselves. The following objectives were set: to achieve by 1980 the growth rate of the developing countries' gross product of at least $6 \%$, per capita product of at least $3.5 \%$, a manufacturing output growth rate of $8 \%$, agricultural output growth of $4 \%$ and annual growth in exports and imports of $7 \%$. To achieve these goals, measures were envisaged to expand trade and economic cooperation and remove barriers to trade, as well as special measures taking into account the special needs of least-developed countries and landlocked countries. The priority source of financing was mobilization of developing countries' resources by strengthening tax administration systems, increasing the efficiency of public enterprises and creating conditions for private investment. Developed countries were expected to provide investments and assistance: By 1972, the target volume of financial resource transfers 
to developing countries were meant to reach a minimum net amount of $1 \%$ of their gross national product at market prices annually. A major part was supposed to be provided in the form of official development assistance (ODA). Each economically developed country should exert its best efforts to reach a minimum net ODA amount of $0.7 \%$ of gross national product (GNP) at market prices by the middle of the decade. A system of measures was provided to ensure a systematic review and assessment of the implementation of goals and objectives at all levels. Thus, for the first time, a comprehensive document was adopted which became the foundation of international development cooperation for the next decades. Financial objectives for assistance in the amount of not less than $1 \%$ of the GNP of economically advanced countries were also recorded in the Declaration of Social Progress and Development, adopted a year earlier at the 24th session of the GA [UN, 1969d].

\section{The Second United Nations Development Decade, 1971-1980: G77 versus G7?}

The key milestones of the Second United Nations Development Decade include the gradual integration of development and environmental issues, efforts to overcome the international monetary crisis and to provide liquidity and financing for development, alleviation of the growing debt burden of developing countries, increased pledging targets for the UNDP, the WFP and special funds, decisions on the development and adoption of the Charter of Economic Rights and Duties of States, efforts to promote implementation of the differential treatment principle with regard to developing countries in the framework of the GATT, preparation and adoption of the International Development Strategy for the Third United Nations Development Decade and the unsuccessful attempt to launch global negotiations on international economic cooperation for development.

At the beginning of the decade, the preparatory process for the UN Conference on the Human Environment (Stockholm Conference) was overshadowed by the struggle between the USSR and the socialist countries on the one hand, and the United States and NATO countries on the other, for the right of the German Democratic Republic to participate on equal terms [UN, 1971a]. ${ }^{7}$ In 1971, on the eve of the conference a GA resolution for the first time laid the principle of common but differentiated responsibility for maintaining ecological balance, and also the sovereign right of each country to exploit its resources in accordance with the needs of development in such a way that its environmental policy does not have a negative impact on economic growth of developing countries. The resolution emphasized that the development of international cooperation to prevent, eliminate or reduce adverse environmental effects should not negatively affect the progress of developing countries, including the deterioration of the terms of trade as a result of creating additional obstacles such as non-tariff barriers, decreases in the inflow of international development assistance and deterioration of its terms and conditions [UN, 1971b]. In December 1972, noting the recommendations of the conference, the GA emphasized that resources for environmental development programmes should be additional in relation to the existing level and the projected growth in resources stipulated in the International Development Strategy [UN, 1972a]. These principles have become fundamental in the UN system for many decades of development cooperation.

In the course of the second decade, the issues of financing for development and servicing developing countries' debt remained acute. According to WB estimates, the growing burden

${ }^{7}$ The German Democratic Republic (GDR) at that time was not a member of any UN agencies. In 1972, the Federal Republic of Germany and the GDR signed the Basic Treaty, and both countries were admitted to the UN in September 1973. At the 26th session, the socialist countries proposed to postpone the conference until 1973 so that the question of the GDR's participation could be raised again at the 27 th session. 
of external debt exceeded \$7,000 million in 1972 [UN, 1972]. The first biennial review of the implementation of the International Development Strategy for the Second United Nations Development Decade showed that the net aggregate transfer of financial resources was lower than planned amounting to $0.69 \%$ of the GDP in 1972, while the ODA level stood at $0.33 \%$ in 1972 , decreasing from 0.86 and 0.50 respectively in 1961 [UN, 1973a]. Inflation, the limited access of developing countries to the financial markets of developed countries and lack of progress in the reform of the international monetary system exacerbated the situation. Reform of the international monetary system [UN, 1973b], replenishment of the International Development Association [UN, 1975a], recapitalization of the IBRD [UN, 1976a, 1979e] and the impact of inflation on the development process [UN, 1977a] remained high on the GA's agenda. The issues of taking into account the interests of developing countries in revising IMF quotas, ensuring greater international liquidity, creating a link between SDRs and additional resources for financing development were discussed at each session of the GA [UN, 1971c]. Steps to reform the international monetary system were limited to measures within the IMF. This was the principled position of the United States, while the Soviet Union, not participating in the IMF, opposed such an approach. At the 34th session of the GA, the United States and its partners opposed [UN, 1976b, p. 450] and subsequently practically blocked the proposals of the Group of 77 to consider a programme of action for further development of the international monetary system so that "progress in this area could contribute to the establishment of the new international economic order" [UN, 1979f].

The United States has consistently opposed resolutions to accelerate the transfer of real resources to developing countries, including to meet the target of $0.7 \%$ of the gross national income, revise rules concerning access of developing countries to capital markets, and reorganize the entire system of debt renegotiation so that it ensures the achievement of development goals rather than commercial ones [UN, 1976c]. The United States also opposed reorganizing the entire debt repayment system and improving access to international capital markets [UN, 1977b].

In 1977 , debts amounted to $\$ 200$ billion, which was the result not only of insufficient assistance, but also reduced export earnings and increased import costs. The GA and UNCTAD had consistently advocated for eliminating trade barriers, urging the participants of the Tokyo Round of multilateral trade negotiations to take into account the interests of developing countries, provide significant concessions on products from the least-developed countries, and preferences for goods from developing countries [UN, 1972c]. The United States objected to the principle of non-reciprocity and differential and special treatment in favour of developing countries, significant reduction in tariff and non-tariff restrictions on the trade of developing countries, and elimination of restrictions in, and improvement of, the generalized system of preferences [UN, 1978a, 1978b, 1979g]. It may be recalled that the results of the Tokyo Round were modest.

Efforts to create an external environment for development were accompanied by measures to strengthen UN mechanisms. UNDP resources were increasing. In the first half of the decade, an objective was set to increase contributions by $15 \%$ annually to promote the goal of doubling resources by 1975 [UN, 1972d]. It was decided that a UN special fund would be established under the auspices of the GA, as a part of the special programme to provide emergency relief and development assistance. The fund was empowered to make grants and loans on concessionary terms, and, as appropriate, to participate in investments to countries most seriously affected by economic crises and to enter into management contracts with the IBRD, the IMF and the regional development banks [UN, 1974]. The objective was set again to ensure the achievement of a funding target of $\$ 1$ billion [UN, 1975b].

In accordance with the objectives in the second development decade to increase growth rates in industrial and agricultural production, specialized development assistance bodies in these areas 
were strengthened. The UN Industrial Development Fund [UN, 1976d] was created to supplement the UN Industrial Development Program. An objective was set to achieve the Industrial Development Fund funding level of $\$ 70$ million by 1979 [UN, 1978c]. Later the resources of the fund and the program were pooled. At the same time the transformation of the UN Industrial Development Organization into a specialized agency [UN, 1977c] and strengthening of operational activities in the field of industrial development began [UN, 1977d]. The target for contributions to the WFP was growing and amounted to $\$ 950$ million for the last biennium of the decade [UN, 1977e]. The International Fund for Agricultural Development with a target amount of funding of SDR 1 billion was established [UN, 1975c]. The growing role of science and technology in facilitating growth and development was reflected in the approval of the Vienna Programme of Action, the decision to establish the Intergovernmental Committee and the Centre for Science and Technology for Development within the UN Secretariat, and the creation of a financing system with expected Interim Fund resources of $\$ 250$ million [UN, 1979a].

In preparing an international development strategy for the third development decade, key programme measures were identified in the areas of improving conditions for agricultural production, developing infrastructure, promoting industrialization, improving the terms of trade, reforming the monetary system and promoting the transfer of technology [UN, 1978d]. It was proposed that the flow of resources to developing countries should significantly increase so that funding during the 1980-1990 decade would amount to $\$ 300$ billion with annual commitments of at least $\$ 25$ billion during the early years [UN, 1979b]. ${ }^{8}$ The International Development Strategy for the Third United Nations Development Decade [UN, 1980a] set even more ambitious goals than its predecessors, envisioning an average annual rate of GDP growth of $7 \%$, per capita gross domestic product growth of about $4.5 \%$ per year, accelerated growth of manufacturing output of about $9 \%$ per year, an increase in the share of developing countries in world manufacturing production to $25 \%$ by 2000 , gross investment of $28 \%$ of GDP by 1990 , and exports and imports growth of $6 \%$ and $8 \%$ respectively.

As the most important condition for the development of developing countries and the growth of the global economy, the objective of intensifying efforts to restructure the international monetary system was postulated: "The international monetary system should provide for the equitable and effective participation of developing countries in decision making, taking into account, inter alia, their growing role in the world economy, as well as a symmetrical and efficient adjustment process, stability of exchange rates of international currencies, and further strengthening and expansion of the special drawing rights as the central reserve asset in order to ensure better international control over the creation and equitable distribution of international liquidity" [UN, 1980a, para. 26].

The parameters of financing for development remained at the level established in the first and second development decades: an increase in ODA to $0.7 \%$ of developed countries' gross national product by 1985 and further growth to $1 \%$. To ensure food security and eradicate hunger, WFP resources must grow to at least $\$ 1$ billion a year. Members of the European Community, the U.S., Canada and Australia expressed their support for the Strategy. The European Community reaffirmed full readiness to make its best effort to achieve the target of $0.7 \%$ of gross national product by the end of the decade [UN, 1980b].

Developing countries, while generally supporting the Strategy, noted that the text did not meet their expectations. Speaking on behalf of the G77, the representative of Venezuela said: "Among the positive aspects of the new Strategy, special reference should be made to the preamble, which clearly recognizes the need for structural change in international relations as well as for the establishment of a new international economic order; the adoption of a scenario of

${ }^{8}$ Belgium, France, Federal Republic of Germany, Japan, the United Kingdom and the United States voted against [UN, 1979c, p. 778]. 
higher general growth targets than in the past Decade, based on an annual growth rate of $7 \%$ of the gross national product of the developing countries, including a time-frame for the attainment of the $0.7 \%$ target for official development assistance, a target carried over laboriously from the previous Strategy; the drawing up of general frameworks for action on two far-reaching issues in the present international situation, namely monetary questions and energy; various important objectives in the area of trade; the particular and unprecedented attention to be devoted to the needs of the special categories of developing countries as an integral concept; and a section on the review and appraisal of the new Strategy, which is considerably stronger than the one agreed upon for the previous Decade."

At the same time, the countries of the G77 stressed that the Strategy did respond to the developing countries aspirations: "In the paragraphs dealing with the economic part, such a large number of reservations and interpretative declarations are made. These indicate not just a lack of political will on the part of many developed countries, but their real opposition to measures for restructuring the international economic system in order to ensure equity, justice and stability in world economic relations, which are unquestionably the fundamental objectives of the new international economic order" [UN, 1980b, p. 93]. The German Democratic Republic, on behalf of the socialist states, supported the provisions of the Strategy, but the socialist states refrained from assuming the obligation to allocate a fixed share of their gross national product for assistance purposes. The socialist countries also noted the Strategy's lack of ambition in comparison with the Declaration on the Establishment of a New International Economic Or$\operatorname{der}^{9}$ and the Charter of Economic Rights and Duties of States [UN, 1980b, p. 82]. ${ }^{10}$

The development and adoption of the Declaration on the Establishment of a New International Economic Order and the Charter of Economic Rights and Duties of States was an attempt to change the global balance of power and ensure full and equal participation of developing countries in the formulation and implementation of all decisions affecting the international community. The ambitious goals stated in the documents were not implemented, nor was the G77 initiative on global negotiations relating to international economic cooperation for development, approved at the 34th session of the GA [UN, 1979d]. This became one of the landmark failures of the third development decade.

The goal of the global negotiations was "the establishment of a new system of international economic relations based on the principles of equality and mutual benefit" [UN, 1979c, pp. 652-3] and a comprehensive solution to such problems as "generalized inflation; unemployment; protectionism; the inadequacy of the financial and monetary systems, the continuing deterioration in the balance of payments and the disorder in trade in raw materials and energy" [Ibid, p. 656]. ${ }^{11}$ The socialist states supported the process.

The text of the resolution stressed that the global round of negotiations "should not involve any interruption or have any adverse effects upon the negotiations in these forums, but should reinforce and draw upon them" [Ibid, p. 652]. ${ }^{12}$ This was the principled position of the United States and developed countries. The United States agreed "to launch a ship called global negotiations," but stressed that "this ship cannot begin its voyage unless our work successfully constructed it." Formally agreeing to the process, the United States opposed its essence: "Regarding paragraph 2, we appreciate the strong desire of many nations to ensure that the global negotiations take place in the United Nations system and that they cover many categories of

${ }^{9}$ The Declaration on the Establishment of a New International Economic Order was adopted by Resolution 3201 (S-VI) of the UN General Assembly on 1 May 1974.

${ }^{10}$ The Charter of Economic Rights and Duties of States was adopted by Resolution 3281 (XXIX) of the UN General Assembly on 12 December 1974.

${ }^{11}$ From a presentation by the representative of Mexico.

${ }^{12}$ From a statement by the representative of Pakistan, who introduced the draft resolution. 
subjects. We support this general concept. But we want to make unambiguously clear that there are certain subjects that can be, and in fact must be, negotiated in their appropriate forums. International monetary issues must be negotiated in IMF; matters related to the General Agreement on Tariffs and Trade must be negotiated in GATT. We can certainly conceive of a structure that would permit the work of these forums and other active specialized forums to be part of the entire process. In this connection, we emphasize that the final phrase of paragraph 2 (a) "without prejudice to the central role of the General Assembly," does not alter the respective roles and powers of the various organizations of the United Nations system that are spelled out in their relationship agreements with the United Nations, nor does it change the recommendatory nature of United Nations General Assembly resolutions and decisions as established in the Charter. We are pleased that paragraph 3 states that global negotiations should neither interrupt nor adversely affect ongoing negotiations. It is our view, for example, that the duplication of active negotiations being held in other forms would represent such an adverse impact" [Ibid, p. 657]. ${ }^{13}$ Thus, the three-decades-long struggle of the G77 to restructure international economic relations and establish a new world order was, in fact, initially doomed to failure. The second decade was marked by undoubted success in strengthening the UN mechanisms for promoting development and agreeing on ambitious goals for the third development decade. At the same time, developing countries' efforts to reform the system of international economic relations faced firm opposition from developed countries.

\section{The Third United Nations Development Decade, 1981-1990: Integrating Environmental Protection into Cooperation for Development}

The third development decade was marked by efforts to strengthen scientific, technical [UN, 1981a $]^{14}$ and industrial potential [UN, 1981b], ${ }^{15}$ develop the energy resources of developing countries [UN, 1982a], ${ }^{16}$ adopt the Global Strategy for Health for All by the year 2000 [UN, 1981c], find a long-term solution to debt problems [UN, 1986a], adopt the Declaration on the Right to Development [UN, 1986b ${ }^{17}$ and prepare and adopt the International Development Strategy for the Fourth United Nations Development Decade. Negative trends in the global economy (economic slowdown, currency instability, increased protectionism, structural imbalances) jeopardized the implementation of the goals of the International Development Strategy for the Third United Nations Development Decade [UN, 1982b]. In this context, efforts of the

${ }^{13}$ From the speech of the U.S. representative.

14 The guiding principles for the financing system were approved: the asymmetry of the technological capacity between developed and developing countries, a predictable, continuous and substantial flow of resources in addition to those existing within the UN system, untied resources, and core resources of $\$ 200$ million per year for the financing system for the period 1983-85.

${ }^{15}$ Decisions were taken to ratify the new constitution of the UN Industrial Development Organization so that it could become a new specialized agency in 1982, to secure the budget of the Industrial Development Fund in the amount of $\$ 50$ million annually, to expand programmes and projects in the field of energy-related industrial technology, and to prepare a UN conference on industrial development in 1984.

${ }^{16}$ For example, by increasing the resources of the World Bank and regional banks on favourable terms for the purposes of exploration and development of natural resources.

${ }^{17}$ Development is a comprehensive economic, social, cultural and political process aimed at constant improvement of the well-being of the entire population and of all individuals on the basis of their active, free and meaningful participation in development and in the fair distribution of benefits resulting therefrom. States are responsible for creating national and international conditions favourable to the realization of the right to development. (146-1 (U.S.) -8) 
international community were focused on three main areas: the restructuring of international economic relations, the implementation of the objectives of the Strategy, the principles of the Declaration on the Establishment of a New International Economic Order and the objectives of the Charter of Economic Rights and Duties of States, and overcoming the external debt crisis [UN, 1988a] while ensuring sufficient resources for development financing [UN, 1988b].

At its 37th session, evaluating the global crisis as a result of the disruption of the structural balance and the functioning of international relations, the GA called for concrete emergency measures in favour of all developing countries on the most pressing issues, including deficits in the balance of payments, deterioration in the terms of trade, adverse effects of high interest rates on the servicing of external debt, insufficient flows of foreign assistance, inequitable terms of technology transfer, impediments to access to the capital markets, and price fluctuations of raw materials [UN, 1982c]. At the same time, the GA recalled the need to conduct global negotiations on international cooperation. Despite the political will of the G77, four years after the decision to launch the preparatory process, constructive dialogue did not begin due to opposition from the United States and its G7 partners. At the 37th session [UN, 1982d] the discussion on the launch of global negotiations was actually blocked by the United States and other G7 members taking the position that the formula adopted in the G7 Versailles Declaration should be the basis for global negotiations: "The launching of global negotiations is a major political objective approved by all participants in the Summit. The latest draft resolution circulated by the Group of 77 is helpful, and the discussion at Versailles showed general acceptance of the view that it would serve as a basis for consultations with the countries concerned. We believe that there is now a good prospect for the early launching and success of the global negotiations, provided that the independence of the specialized agencies is guaranteed" [G7, 1982]. The G77's objection that "the Versailles communique, instead of facilitating the negotiations which we would have believed to be a rational and logical response, has instead created a stalemate" [UN, 1982e, p. 918], faced a formal U.S. response: "Realism requires that we recognize remaining differences on global negotiations and that we candidly discuss and try to co-operate in reconciling them" [Ibid, p. 921]. At the 38th session, the G7 actually pushed the Versailles formula as the basis for negotiations, but even after their launch, the condition of guaranteeing the independence of the specialized agencies created an insurmountable obstacle to finding comprehensive solutions to the restructuring of international economic relations, taking into account the growing role and needs of developing countries.

Measures to resolve external debt problems were discussed at almost every session. Considering that developing countries' debts became an obstacle to economic growth, increased the vulnerability of the international financial system, adversely affected the ability of debtor countries to import and creditors to export, and created risks for political and social stability, the GA called for strengthened work on the preparation of an international growth- and development-oriented strategy [UN, 1987a]. The strategy to find a durable solution to the debt problem proposed at the 44th session formulated as a priority the creation of conditions for growth and development, including the successful conclusion of the Uruguay Round of trade negotiations to improve market access for the export products of developing countries, active efforts to diversify exports of developing countries, an increase in external resources to complement domestic measures conducive to capital formation in developing countries, a strengthened role for multilateral financial institutions, and readiness of creditor countries to write off or reduce debts [UN, 1989a]. The United States voted against the resolution, believing that it did not pay enough attention to the needs of domestic reforms in developing countries, did not recognize the key role of the IMF and the World Bank, and raised issues that should be discussed in other specialized agencies. Nevertheless, at the next session, the resolution was adopted without a vote [UN, 1990b].

Development issues were often used as instruments in the political struggle by both developed and developing countries. In the 1980s, six resolutions were adopted calling on the 
United States to abandon the threat or use of trade embargoes, restrictions and other measures as a form of political and economic coercion which violate the sovereign rights of developing states. ${ }^{18}$ In the fourth development decade, such resolutions were adopted every two years [UN, 1983, 1984, 1985, 1986c, 1987b, 1989b].

Resolutions were usually initiated by the G77, supported by the socialist countries, but rejected by the United States and its partners. ${ }^{19}$ In fact, if development assistance measures were used by developed countries in relation to developing ones as "carrots," then measures of economic coercion were applied as "sticks." It is clear that such measures violated the spirit and the letter of the UN Charter and the programme documents of the organization, including the Charter of Economic Rights and Duties of States. Therefore, the United States consistently opposed resolutions to review the implementation of the charter [UN, 1982f].

\section{Box}

Despite geopolitical changes and obvious inefficiency, the practice of adopting resolutions condemning the use of sanctions continued in the 1990s. Seven such resolutions were adpted. In the mid-1990s, the extraterritorial use of sanctions by the U.S. against European companies operating in Iran and Libya changed the balance in voting. At the 51st session, the United States was supported only by Israel, Micronesia and Uzbekistan [UN, 1996b]; at the 52nd session, only the United States opposed the resolution [UN, 1997a]. At the 53rd session European Union members stated they were against sanctions but abstained from voting, and the U.S. was supported only by Israel [UN, 1998a]. Sanctions against Yugoslavia in December 1999 were supported by Germany and the Marshall Islands [UN, 1999a].

${ }^{18}$ In 1983, 1984, 1985, 1986, 1987, 1989. In the 1980s, U.S. sanctions were imposed against Brazil (197881), Argentina (1978-82), Bolivia (1979-82), India (1978-82) and Iran (1979-81). From the late 1970s to the 2000s U.S. sanctions were in force against Pakistan (1979-2001), Libya (1978-2004) and Iraq (1980-2003). In the 1980s, the United States imposed sanctions against Nicaragua (1981-90), Zimbabwe (1983-88), Iran (1984-), Lebanon (1984-97), South Africa (1985-91), Syria (1986-), Angola (1986-92), Sudan (1989-) and others. In the 1990s sanctions were imposed against China (1991-), Indonesia (1991-97), Peru (1991-95), Cameroon (1992-98), Cambodia (1992-), Guatemala (1993), Nigeria (1993-98) and others. From 1991 to 2001, EU and U.S. sanctions were effective against Yugoslavia. Sanctions against the USSR were imposed periodically. See Hufbauer et al. [2009, pp. 20-33].

${ }^{19}$ For example, draft resolution 39/210 was adopted by 116 votes to 19, with 6 abstentions: For: Afghanistan, Albania, Algeria, Angola, Argentina, Bahamas, Bahrain, Bangladesh, Barbados, Benin, Bhutan, Bolivia, Botswana, Brazil, Brunei Darussalam, Bulgaria, Burkina Faso, Burma, Burundi, Belarusian Soviet Socialist Republic, Republic of Cape Verde, Chad, Chile, China, Colombia, Congo, Costa Rica, Cuba, Cyprus, Czechoslovakia, Democratic Kampuchea, Democratic Yemen, Djibouti, Dominican Republic, Ecuador, Egypt, El Salvador, Equatorial Guinea, Ethiopia, Fiji, Gabon, Gambia, German Democratic Republic, Ghana, Guatemala, Guinea, Guinea-Bissau, Guyana, Haiti, Honduras, Hungary, India, Indonesia, Iran (Islamic Republic), Jordan, Kenya, Kuwait, Laos Democratic People's Republic, Lebanon, Liberia, Libyan Arab Jamahiriya, Malawi, Malaysia, Maldives, Mali, Malta, Mauritania, Mauritius, Mexico, Mongolia, Morocco, Mozambique, Nepal, Nicaragua, Niger, Nigeria, Oman, Pakistan, Panama, Papua New Guinea, Paraguay, Peru, Philippines, Poland, Qatar, Romania, Rwanda, Saint Vincent and the Grenadines, Samoa, Sao Tome and Principe, Saudi Arabia, Senegal, Sierra Leone, Singapore, Somalia, Sri Lanka, Sudan, Spins, Swaziland, Syrian Arab Republic, Thailand, Togo, Trinidad and Tobago, Tunisia, Uganda, Ukrainian Soviet Socialist Republic, Union of Soviet Socialist Republics, United Arab Emirates, United Republic of Tanzania, Uruguay, Venezuela, Vietnam, Yemen, Yugoslavia, Zaire, Zambia.

Against: Australia, Belgium, Canada, Denmark, France; Germany, the Federal Republic of Iceland, Ireland, Israel, Italy, Japan, Luxembourg, the Netherlands, New Zealand, Norway, Portugal, Turkey, the United Kingdom, the United States.

Abstained: Austria, Finland, Greece, Ivory Coast, Spain, Sweden. 
Resolutions on the relationship between disarmament and development providing for the use of resources released through disarmament for development purposes also became stumbling blocks [UN, 1984, 1987c, 1988c, 1989d]. They built on the initiative put forward by the USSR in 1973 at the 28th session of the GA [UN, 1973c]. The United States refused to take part in the international conference on this issue, refrained from participating in the preparation of the draft resolution and did not "consider itself bound or committed in any way by either the declarations in the Final Document of the recent International Conference or the terms of any resolution" adopted there [UN, 1987d, p. 13]..$^{20}$

The achievements of the third decade included decisions on sustainable development. The report of the World Commission on Environment and Development for the first time set the objective of reorienting national and international policies toward sustainable development models, which implied that "meeting the needs of the present without compromising the ability of future generations to meet their own needs, should become a central guiding principle." [UN, 1987e] The GA called on the governing bodies, organizations and programmes of the United Nations system to review their activities and programmes through the lens of sustainable development and to link development plans, priorities and objectives with sustainable development commitments. The principle of an equitable sharing of the environmental costs was formulated [UN, 1987e]. At its $44^{\text {th }}$ session the GA stressed that "poverty and environmental degradation are closely interrelated and that environmental protection in developing countries must, in this context, be viewed as an integral part of the development process and cannot be considered in isolation from it" agreed to convene the UN conference on environment and development. The Conference held in June 1992 confirmed the principle in the Rio Declaration [UN, 1992d]. Plans were made to elaborate measures to promote sustainable and environmentally sound development, to identify ways and means of providing new and additional resources, particularly to developing countries, for environmentally sound development programmes and projects, and to consider financing mechanisms and examine the possibility of creating a special fund [UN, 1989e]. These aspects were reflected in the International Development Strategy for the Fourth United Nations Development Decade.

The Strategy included six interrelated goals: a surge in the pace of economic growth in developing countries; ensuring a development process that is responsive to social needs and seeks a significant reduction in poverty, that promotes the development of human resources and is environmentally sound and sustainable; improving the international monetary, financial and trading systems to support development; ensuring the sustainability and stability of the world economy and sound macroeconomic management; strengthening international development cooperation; and mobilizing efforts to deal with the problems of the least-developed countries. Measures to protect and enhance the environment were included in priority aspects of development [UN, 1990a].

The Strategy has become an important milestone in the evolution of cooperation for sustainable development. However, it should be recognized that the decade was not a period of great achievements. Common tasks and problems have neither united countries with different ideologies, nor helped overcome national egoism.

${ }^{20}$ The history of this issue deserves separate consideration and will be presented in an article devoted to the participation of the USSR in the process of establishing a development assistance system under the auspices of the UN. 


\section{The Fourth United Nations Development Decade, 1991-2000: Toward a Global Partnership for Development}

The beginning of the fourth development decade was marked by the end of the collapse of the USSR and the world socialist system. The Russian Federation became the successor of the USSR in international legal relations and in the UN system. The process of restructuring and integration of the socialist countries into the world economy and structures of international economic cooperation began. Developing countries whose economies were affected by changes in their economic relations with the countries of Eastern and Central Europe [UN, 1991a] were concerned about a possible reduction in development assistance as a result of support for countries with economies in transition. These concerns were discussed in the GA and reflected in relevant UN resolutions [UN, 1992a].

A resolution of the growing debt crisis was heatedly debated at all sessions, but this did not lead to fundamental changes and could not prevent the financial crisis. Measures to write off and restructure debts were clearly not sufficient [UN, 1991b, 1992b, 1994, 1995a]. The reform of the international financial system blocked by the U.S. determination to maintain independence of and control over the IMF and the World Bank, and therefore was limited to rhetorical calls by the GA to strengthen collaboration between the UN and the Bretton Woods institutions [UN, 1996a]. In 1997, on the eve of the financial crisis, the GA once again called for strengthening international cooperation to prevent future currency crises, including by coordinating and ensuring the stability of macroeconomic policies, increasing transparency of financial systems, and strengthening the IMF's surveillance mechanisms [UN, 1997b]. After the 1998 crisis, little had changed; key theses on the need for sound macroeconomic policies and a dialogue between developed and developing countries on reforming and strengthening the international financial system were complemented by the objectives of formulating a global approach to resolve the financial crisis; improving the work of financial organizations to prevent, manage and overcome crises; strengthening joint efforts of the UN, WB, IMF, RDBs and WTO [UN, 1998b]. The United States continued to oppose the consideration in the UN of issues such as governance of the IMF, the World Bank or regional development banks, or the problems related to the international financial architecture, emphasizing that it is the prerogative of the institutions themselves, the Financial Stability Forum and the Group of 20 [UN, 1999b, p. 6]. This approach is reflected in the UN resolution "Towards a Strengthened and Stable International Financial Architecture Responsive to the Priorities of Growth and Development, Especially in Developing Countries, and to the Promotion of Economic and Social Equity" [UN, 2000a] ${ }^{21}$

${ }^{21}$ From the speech of the U.S. representative at the meeting: "After lengthy and frank negotiations, we believe that this year's draft resolution shows clear acceptance of the division of labour between the United Nations and the Bretton Woods institutions. The United Nations, as a political organization of the international community, represents the political views of its Members. The Bretton Woods institutions, as separate financial institutions with their own charters and mandates, enjoy organizational and decision-making independence in dealing with world financial matters. We believe it is essential that the full independence of the international financial institutions be completely respected and upheld, especially in a number of areas mentioned in the draft resolution. These include, but are not limited to, such areas of concern as the suggestion of regulatory frameworks for short-term capital flows and trade in currencies, as well as the consideration of the consolidation of a broader global agenda regarding the international financial system. In addition, we believe that it is critical that regional cooperation should support, not supplant, the global efforts of the international financial institutions. The international community recognizes the need to strengthen the international financial system. Experience has shown that international financial institutions are the most effective actors to help achieve that goal. Their independence, as well as their technical expertise and focus, are crucial to their credibility, and therefore to the success of their work. We fully expect that the international community will do everything it can to protect this credibility" [UN, 2000b, p. 6]. 
and, in fact, determined both the rigidity of the system for many years and its failure to prevent the 2008 crisis.

In the1990s, new aspects emerged in the area of trade and development related to helping developing countries to implement the provisions of the Final Act Embodying the Results of the Uruguay Round of Multilateral Trade Negotiations, including technical assistance for the wider use of the dispute settlement mechanism [UN, 1998c]. In the area of environmental preservation, measures to facilitate and finance access to environmentally sound technologies and the corresponding know-how, and their transfer to developing countries on concessional and preferential terms, were discussed [UN, 1995b].

Regular reviews of the implementation of the International Development Strategy for the Fourth United Nations Development Decade and the commitments and policies agreed upon in the Declaration on International Economic Cooperation have become important components of cooperation. Relevant reports served as a basis for assessing progress and formulating proposals for a future agenda. ${ }^{22}$

The development of a new agenda and a global partnership for sustainable development was launched by a resolution adopted in March 1993 which set as an objective the preparation of a report on an agenda for development, including a comprehensive list of themes and areas, indicating their priority for the consideration of member states [UN, 1992c]. The long and extensive preparatory process culminated in the adoption of the Agenda for Development on 20 June 1997 [UN, 1997c]. The document defined development as "a multidimensional undertaking to achieve a higher quality of life for all people," in which "economic development, social development and environmental protection are interdependent and mutually reinforcing components of sustainable development" [para. 1]. The Agenda for Development reflected the changed conditions of international cooperation, including the end of the Cold War, the globalization of the world economy and finance, increasing interdependence and mutual vulnerability, and the impact of these processes on developing countries and development. Accordingly, key objectives for strengthening international development cooperation and promoting development through an integrated approach were formulated.

The document incorporated all aspects and areas of cooperation. In economic policy, it provided for coordination of macroeconomic policies, liberalization of international trade, mobilization of domestic and external financial resources including the "peace dividend," domestic capacity-building in science and technology, expansion of the potential for South-South cooperation and regional economic cooperation, and balanced development in agriculture, industry and the services sectors. Social development priorities included eradication of hunger and poverty, expansion of productive employment, social integration, human resources development and provision of adequate housing. The Agenda included issues such as the empowerment of women, the rights of the child, international migration, humanitarian issues, and measures relating to countries in special situations (Africa, least-developed countries, small island states, landlocked countries). In the field of the environment, the document set as an objective the full implementation of the Agenda for the 21 century. Special attention was paid to the role of the UN and its bodies, the role of specialized agencies and the UN's interaction with other multilateral institutions, including the Bretton Woods institutions and the WTO.

The Agenda for Development has become an important milestone in shaping the future global partnership and a basis for elaborating the United Nations Millennium Declaration. The goals of the Declaration - eradicating poverty and hunger, achieving universal primary education, reducing child mortality, improving maternal health, empowering women, fighting HIV/ AIDS, malaria and other diseases, protecting the environment, and building a global partner-

${ }^{22}$ They were adopted at each session, the last in a decade [UN, 2000c]. 
ship for development - identified modalities and areas of development cooperation in the first 15 years of the 21 st century [UN, 2000d].

\section{Conclusion}

The international community has come a long way toward building development cooperation in the second-half of the 20th century. The UN has become a cradle and a driver of this process and is the main factor for its success. The share of resolutions on development cooperation in the total number of resolutions comprised 10\% (1010 out of 9713). The greatest number was adopted in the first two development decades, the period of elaborating instruments, developing first policy documents, identifying development priorities and harmonizing approaches to financing. The formation of the regulatory and organizational framework was reflected in the progressive growth in the share of programme resolutions and the consistently high proportion of resolutions on organizational and administrative issues. The share of resolutions on creating development assistance instruments, which was quite high in the early years, decreased with the completion of institutional development. The role of trade in development determines the permanent presence of trade facilitation issues and problems of ensuring access to international markets for developing countries on the GA's agenda. The special needs of the least-developed countries and other country categories that were most urgent in the early years retain their importance, but their share has significantly diminished. The problem of financing development was a cross-cutting issue in all decades. However, in the first decades priorities included accelerating the flow of international aid and long-term capital, whereas starting from the mid-1960s debt relief issues, problems of international liquidity and international financial system reform emerged.

There were achievements and challenges at each stage. Indisputable achievements resulting from collective efforts over 55 years include a consistent consolidation of its foundational programme documents from the first development decade to the sustainable development agenda, improvement of the review and evaluation instruments, integration of development and environmental issues, establishment of key institutions, including the Children's Fund, the Special Fund, UNDP, UNCTAD, the United Nations Industrial Cooperation Organization and the World Food Program, and increased financing for development. However, efforts to create external conditions for development based on a restructuring the international economic system with regard to developing countries' interests have failed. The 21 st century inherited the systemic problems of the international monetary and trading systems. Obviously, if national egoism, political and ideological differences could have been overcome, the achievements of cooperation for development would have been much more significant.

\section{References}

Alonso J.A., Glennie J. (2015) What Is Development Cooperation? ECOSOC Development Cooperation Forum Policy Briefs no 1. Available at: http://www.un.org/en/ecosoc/newfunct/pdf15/2016_dcf_ policy_brief_no 1.pdf (accessed 14 August 2018).

Group of 7 (1982) Declaration of the Seven Heads of State and Government and Representatives of the European Communities. Versailles, 4-6 June. Available at: http://www.g8.utoronto.ca/ summit/1982versailles/communique.html (accessed 14 August 2018).

Hufbauer G.C., Schott J.J., Eliot K.A., Oegg B. (2009) Economic Sanctions Reconsidered. 3rd edition. Washington DC: Peterson Institute for International Economics. Available at: https://piie.com/publications/chapters_preview/4075/01iie4075.pdf (accessed 14 August 2018). 
Shumilov V.M. (2005) International Public Economic Law. Moscow: International Relations.

United Nations (UN) (1946) Agreements with Specialized Agencies. General Assembly Resolution A/ RES/50 (1). Available at: https://undocs.org/en/A/RES/50(I) (accessed 14 August 2018).

United Nations (UN) (1947a) Agreements with Specialized Agencies. General Assembly Resolution A/ RES/124 (II). Available at: https://undocs.org/en/A/RES/124(II) (accessed 14 August 2018).

United Nations (UN) (1947b) Reports on World Economic Conditions and Trends. General Assembly Resolution A/RES/118 (II). Available at: https://undocs.org/en/A/RES/118(II) (accessed 14 August 2018).

United Nations (UN) (1947c) Implementation of Recommendations on Economic and Social Matters. General Assembly Resolution A/RES/119 (II). Available at: https://undocs.org/en/A/RES/119(II) (accessed 14 August 2018).

United Nations (UN) (1948a) Economic Development of Under-Developed Countries. General Assembly Resolution A/RES/198 (III). Available at: https://undocs.org/en/A/RES/198(III) (accessed 14 August 2018).

United Nations (UN) (1948b) Technical Assistance for Economic Development. General Assembly Resolution A/RES/200 (III). Available at: https://undocs.org/en/A/RES/200(III) (accessed 14 August 2018).

United Nations (UN) (1949) Economic Development and International Economic and Commercial Policy. General Assembly Resolution A/RES/307 (IV). Available at: https://undocs.org/en/A/RES/307(IV) (accessed 14 August 2018).

United Nations (UN) (1950) Financing Economic Development of Under-Developed Countries. General Assembly Resolution A/RES/400 (V). Available at: https://undocs.org/en/A/RES/400(V) (accessed 14 August 2018).

United Nations (UN) (1952a) Financing of Economic Development of Under-Developed Countries. General Assembly Resolution A/RES/520 (VI). Available at: https://undocs.org/en/A/RES/520(VI) (accessed 14 August 2018).

United Nations (UN) (1952b) Official Records of the General Assembly, Sixth Session. Available at: http://www.un.org/en/ga/search/view_doc.asp?symbol=A/PV.360 (accessed 14 August 2018).

United Nations (UN) (1953) A. Economic Development of Underdeveloped Countries. General Assembly Resolution A/RES/724(VIII). Available at: http://www.un.org/en/ga/search/view_doc. asp?symbol=A/RES/724(VIII) (accessed 14 August 2018).

United Nations (UN) (1954a) Question of the Establishment of an International Finance Corporation. General Assembly Resolution A/RES/823(IX). Available at: http://www.un.org/en/ga/search/view_doc. asp?symbol=A/RES/823(IX) (accessed 14 August 2018).

United Nations (UN) (1954b) Question of the Establishment of a Special United Nations (UN) Fund for Economic Development. General Assembly Resolution A/RES/822(IX). Available at: http://www. un.org/en/ga/search/view_doc.asp?symbol=A/RES/822(IX) (accessed 14 August 2018).

United Nations (UN) (1955) Confirmation of Allocation of Funds Under the Expanded Programme of Technical Assistance. General Assembly Resolution A/RES/994 (X). Available at: https://undocs.org/ en/A/RES/994(X) (accessed 14 August 2018).

United Nations (UN) (1956a) Official Records of the General Assembly, Eleventh Session. Available at: https://undocs.org/en/A/PV.632 (accessed 14 August 2018).

United Nations (UN) (1956b) Currency Utilization. General Assembly Resolution A/RES/1021 (XI). Available at: https://undocs.org/en/A/RES/1021(XI) (accessed 14 August 2018).

United Nations (UN) (1957a) Financing of Economic Development. General Assembly Resolution A/ RES/1219 (XII). Available at: https://undocs.org/en/A/RES/1219(XII) (accessed 14 August 2018).

United Nations (UN) (1957b) Official Records of the General Assembly, Twelfth Session. Available at: https://undocs.org/en/A/PV.730 (accessed 14 August 2018). 
United Nations (UN) (1957c) Industrialization of Underdeveloped Countries. General Assembly Resolution A/RES/1033 (XI). Available at: https://undocs.org/en/A/RES/1033(XI) (accessed 14 August 2018).

United Nations (UN) (1957d) Development of International Economic Cooperation and the Expansion of International Trade. General Assembly Resolution A/RES/1027 (XI). Available at: https://undocs. org/en/A/RES/1027(XI) (accessed 14 August 2018).

United Nations (UN) (1958a) Establishment of the Special Fund. General Assembly Resolution A/ RES/1240 (XIII). Available at: https://undocs.org/en/A/RES/1240(XIII) (accessed 14 August 2018).

United Nations (UN) (1958b). Official Records of the General Assembly, Thirteenth Session. Available at: https://undocs.org/en/A/PV.776. (accessed 14 August 2018)

United Nations (UN) (1959a) Confirmation of Allocation of Funds for the Expanded Programme of Technical Assistance in 1960. General Assembly Resolution A/RES/1432 (XIV). Available at: https:// undocs.org/en/A/RES/1432(XIV) (accessed 14 August 2018).

United Nations (UN) (1959b) Progress and Operations of the Special Fund. General Assembly Resolution A/RES/1382 (XIV). Available at: https://undocs.org/en/A/RES/1382(XIV) (accessed 14 August 2018).

United Nations (UN) (1959c) Strengthening and Development of the World Market and Improvement of the Trade Conditions of the Economically Less Developed Countries. General Assembly Resolution A/RES/1421 (XIV). Available at: https://undocs.org/en/A/RES/1421(XIV) (accessed 14 August 2018).

United Nations (UN) (1959d) International Measures to Assist in Offsetting Fluctuation in Commodity Prices. General Assembly Resolution A/RES/1423 (XIV). Available at: https://undocs.org/en/A/ RES/1423(XIV) (accessed 14 August 2018).

United Nations (UN) (1959e) Official Records of the General Assembly, Fourteenth Session. Available at: https://undocs.org/en/A/PV.846 (accessed 14 August 2018).

United Nations (UN) (1960a) Contributions to the Special Fund and to the Expanded Programme of Technical Assistance. General Assembly Resolution A/RES/1529 (XV). Available at: https://undocs.org/ en/A/RES/1529(XV) (accessed 14 August 2018).

United Nations (UN) (1960b) Accelerated Flow of Capital and Technical Assistance to the Developing Countries. General Assembly Resolution A/RES/1522 (XV). Available at: https://undocs.org/en/A/ RES/1522(XV) (accessed 14 August 2018).

United Nations (UN) (1960c) Establishment of the United Nations (UN) Capital Development Fund. General Assembly Resolution A/RES/1521 (XV). Available at: https://undocs.org/en/A/RES/1521(XV) (accessed 14 August 2018).

United Nations (UN) (1960d) Improvements of the Terms of Trade Between the Industrial and the Underdeveloped Countries. General Assembly Resolution A/RES/1520(XV). Available at: https://undocs. org/en/A/RES/1520(XV) (accessed 14 August 2018).

United Nations (UN) (1960e) Financing of Economic Development of Less Developed Countries Through Long-Term Loans and in Other Advantageous Ways, and Ensuring an Increasing Share in World Trade for Their Products. General Assembly Resolution A/RES/1524 (XV). Available at: https:// undocs.org/en/A/RES/1524(XV) (accessed 14 August 2018).

United Nations (UN) (1960f) Official Records of the General Assembly, Fifteenth Session. Available at: https://undocs.org/en/A/PV.908 (accessed 14 August 2018).

United Nations (UN) (1960g) Provision of Food Surpluses to Food-Deficient Peoples Through the United Nations (UN) System. General Assembly Resolution A/RES/1496 (XV). Available at: https:// undocs.org/en/A/RES/1496(XV) (accessed 14 August 2018).

United Nations (UN) (1961a) United Nations (UN) Development Decade - A Programme for International Economic Cooperation. General Assembly Resolution A/RES/1710 (XVI). Available at: https:// undocs.org/en/A/RES/1710(XVI) (accessed 14 August 2018). 
United Nations (UN) (1961b) Reaffirmation of General Assembly Resolution 1522 (XV) On the Accelerated Flew of Capital and Technical Assistance to the Developing Countries. General Assembly Resolution A/RES/1711 (XVI). Available at: https://undocs.org/en/A/RES/1711(XVI) (accessed 14 August 2018).

United Nations (UN) (1961c) World Food Programme. General Assembly Resolution A/RES/1714 (XVI). Available at: https://undocs.org/en/A/RES/1714(XVI) (accessed 14 August 2018).

United Nations (UN) (1961d) International Trade as the Primary Instrument for Economic Development. General Assembly Resolution A/RES/1707 (XVI). Available at: https://undocs.org/en/A/ RES/1707(XVI) (accessed 14 August 2018).

United Nations (UN) (1963a) Activities in the Field of Industrial Development. General Assembly Resolution A/RES/1940 (XVIII). Available at: https://undocs.org/en/A/RES/1940(XVIII) (accessed 14 August 2018).

United Nations (UN) (1963b) Official Records of the General Assembly, Eighteenth Session. Available at: https://undocs.org/en/A/PV.1256 (accessed 14 August 2018).

United Nations (UN) (1965a) Consolidation of the Special Fund and the Expanded Programme of Technical Assistance in a United Nations (UN) Development Programme. General Assembly Resolution A/ RES/2029 (XX). Available at: https://undocs.org/en/A/RES/2029(XX) (accessed 14 August 2018).

United Nations (UN) (1965b) Consolidation of the Special Fund and the Expanded Programme of Technical Assistance in a United Nations (UN) Development Programme. General Assembly Resolution A/ RES/2029 (XX). Available at: https://undocs.org/en/A/RES/2029(XX) (accessed 14 August 2018).

United Nations (UN) (1965c) Establishment of the United Nations (UN) Organizations for Industrial Development. General Assembly Resolution A/RES/2089 (XX). Available at: https://undocs.org/en/A/ RES/2089(XX) (accessed 14 August 2018).

United Nations (UN) (1965d) Establishment of the United Nations (UN) Conference on Trade and Development as an Organ of the General Assembly. General Assembly Resolution A/RES/1995 (XIX). Available at: https://undocs.org/en/A/RES/1995(XIX) (accessed 14 August 2018).

United Nations (UN) (1966a) United Nations (UN) Industrial Development Organization. General Assembly Resolution A/RES/2152 (XXI). Available at: https://undocs.org/en/A/RES/2152(XXI) (accessed 14 August 2018).

United Nations (UN) (1966b) General Review of the Programmes and Activities in the Economic, Social, Technical Cooperation and Related Fields of the United Nations (UN), the Specialized Agencies, the International Atomic Energy Agency, the United Nations (UN) Children's Fund and All Other Institutions and Agencies Related to the United Nations (UN) System. General Assembly Resolution A/ RES/2188 (XXI). Available at: https://undocs.org/en/A/RES/2188(XXI) (accessed 14 August 2018).

United Nations (UN) (1966c) United Nations (UN) Development Decade. General Assembly Resolution A/RES/2218 (XXI). Available at: https://undocs.org/en/A/RES/2218(XXI) (accessed 14 August 2018).

United Nations (UN) (1966d) World Social Situation. General Assembly Resolution A/RES/2215 (XXI). Available at: https://undocs.org/en/A/RES/2215(XXI) (accessed 14 August 2018).

United Nations (UN) (1966e) External Financing of Economic Development of Developing Countries. General Assembly Resolution A/RES/2169 (XXI). Available at: https://undocs.org/en/A/ RES/2169(XXI) (accessed 14 August 2018).

United Nations (UN) (1966f) Flow of External Resources to Developing Countries. General Assembly Resolution A/RES/2170 (XXI). Available at: https://undocs.org/en/A/RES/2170(XXI) (accessed 14 August 2018).

United Nations (UN) (1966g) International Monetary Reform. General Assembly Resolution A/ RES/2208 (XXI). Available at: https://undocs.org/en/A/RES/2208(XXI) (accessed 14 August 2018). 
United Nations (UN) (1967) United Nations (UN) Capital Development Fund. General Assembly Resolution A/RES/2321 (XXII). Available at: https://undocs.org/en/A/RES/2321(XXII) (accessed 14 August 2018).

United Nations (UN) (1968a) International Monetary Reform. General Assembly Resolution A/ RES/2461 (XXIII). Available at: https://undocs.org/en/A/RES/2461(XXIII) (accessed 14 August 2018).

United Nations (UN) (1968b) Problems of the Human Environment. General Assembly Resolution A/ RES/2398 (XXIII). Available at: https://undocs.org/en/A/RES/2398(XXIII) (accessed 14 August 2018).

United Nations (UN) (1969a) Target for Pledges to the World Food Programme for the Period 19711972. General Assembly Resolution A/RES/2527 (XXIV). Available at: https://undocs.org/en/A/ RES/2527(XXIV) (accessed 14 August 2018).

United Nations (UN) (1969b) International Monetary Reform. General Assembly Resolution A/ RES/2565 (XXIV). Available at: https://undocs.org/en/A/RES/2565(XXIV) (accessed 14 August 2018).

United Nations (UN) (1969c) Declaration on Social Progress and Development. General Assembly Resolution A/RES/2542 (XXIV). Available at: https://undocs.org/en/A/RES/2542(XXIV) (accessed 14 August 2018).

United Nations (UN) (1969d) Declaration on Social Progress and Development. General Assembly Resolution A/RES/2542 (XXIV). Available at: https://undocs.org/en/A/RES/2542(XXIV) (accessed 14 August 2018).

United Nations (UN) (1970a) Official Records of the General Assembly, Twenty-Fifth Session. Available at: https://undocs.org/en/A/PV.1918 (accessed 14 August 2018).

United Nations (UN) (1970b) United Nations (UN) Conference on the Human Environment. General Assembly Resolution A/RES/2657 (XXV). Available at: https://undocs.org/en/A/RES/2657(XXV) (accessed 14 August 2018).

United Nations (UN) (1970c) International Development Strategy for the Second United Nations (UN) Development Decade. General Assembly Resolution A/RES/2626 (XXV). Available at: https://undocs. org/en/A/RES/2626(XXV) (accessed 14 August 2018).

United Nations (UN) (1971a) Official Records of the General Assembly, Twenty-Sixth Session. Available at: https://undocs.org/en/A/PV.2026 (accessed 14 August 2018).

United Nations (UN) (1971b) Development and Environment. General Assembly Resolution A/ RES/2849 (XXVI). Available at: https://undocs.org/en/A/RES/2849(XXVI) (accessed 14 August 2018).

United Nations (UN) (1971c) International Currency Situation. General Assembly Resolution A/ RES/2807 (XXVI). Available at: https://undocs.org/en/A/RES/2807(XXVI) (accessed 14 August 2018).

United Nations (UN) (1972a) Development and Environment. General Assembly Resolution A/ RES/3002 (XXVII). Available at: https://undocs.org/en/A/RES/3002(XXVII) (accessed 14 August 2018).

United Nations (UN) (1972b) External Debt Servicing by the Developing Countries. General Assembly Resolution A/RES/3039 (XXVII). Available at: https://undocs.org/en/A/RES/3039(XXVII) (accessed 14 August 2018).

United Nations (UN) (1972c) Multilateral Trade Negotiations. General Assembly Resolution A/ RES/3040 (XXVII). Available at: https://undocs.org/en/A/RES/3040(XXVII) (accessed 14 August 2018).

United Nations (UN) (1972d) Financial Resources of the United Nations (UN) Development Programme. General Assembly Resolution A/RES/2973 (XXVII). Available at: https://undocs.org/en/A/ RES/2973(XXVII) (accessed 14 August 2018).

United Nations (UN) (1973a) First Biennial Over-All Review and Appraisal of Progress in the Implementation of the International Development Strategy for the Second United Nations (UN) Development Decade. General Assembly Resolution A/RES/3176 (XXVIII). Available at: https://undocs.org/en/A/ RES/3176(XXVIII) (accessed 14 August 2018). 
United Nations (UN) (1973b) Reform of International Monetary System. General Assembly Resolution A/RES/3084 (XXVIII). Available at: https://undocs.org/en/A/RES/3084(XXVIII) (accessed 14 August 2018).

United Nations (UN) (1973c) Reduction of the Military Budgets of States Permanent Members of the Security Council by 10 Per Cent and Utilization of Part of the Funds Thus Saved to Provide Assistance to Developing Countries. General Assembly Resolution A/RES/3093. Available at: https://undocs.org/ en/A/RES/3093(XXVIII) (accessed 14 August 2018).

United Nations (UN) (1974) United Nations (UN) Special Fund. General Assembly Resolution A/ RES/3356 (XXIX). Available at: https://undocs.org/en/A/RES/3356(XXIX) (accessed 14 August 2018).

United Nations (UN) (1975a) Fifth Replenishment of the International Development Association. General Assembly Resolution A/RES/3387 (XXX). Available at: https://undocs.org/en/A/RES/3387(XXX) (accessed 14 August 2018).

United Nations (UN) (1975b) United Nations (UN) Special Fund. General Assembly Resolution A/ RES/3460 (XXX). Available at: https://undocs.org/en/A/RES/3460(XXX) (accessed 14 August 2018).

United Nations (UN) (1975c) Establishment of an International Fund for Agricultural Development. General Assembly Resolution A/RES/3503 (XXX). Available at: https://undocs.org/en/A/ RES/3503(XXX) (accessed 14 August 2018).

United Nations (UN) (1976a) Recapitalization of the International Bank for Reconstruction and Development and Replenishment of the International Development Association. General Assembly Resolution A/RES/31/181. Available at: https://undocs.org/en/A/RES/31/181

United Nations (UN) (1976b) Official Records of the General Assembly, Thirty-First Session. Available at: https://undocs.org/en/A/31/PV.106 (accessed 14 August 2018).

United Nations (UN) (1976c) Ways and Means of Accelerated the Transfer of Real Resources to Developing Countries on a Predictable, Assured and Continuous Basis. General Assembly Resolution A/ RES/31/174. Available at: https://undocs.org/en/A/RES/31/174 (accessed 14 August 2018).

United Nations (UN) (1976d) Establishment of the United Nations (UN) Industrial Development Fund. General Assembly Resolution A/RES/31/202. Available at: https://undocs.org/en/A/RES/31/202 (accessed 14 August 2018).

United Nations (UN) (1977a) Effects of the World Inflationary Phenomenon on the Development Process. General Assembly Resolution A/RES/32/175. Available at: https://undocs.org/en/A/RES/32/175 (accessed 14 August 2018).

United Nations (UN) (1977b) Debt Problems of Developing Countries. General Assembly Resolution A/ RES/32/187. Available at: https://undocs.org/en/A/RES/32/187 (accessed 14 August 2018).

United Nations (UN) (1977c) United Nations (UN) Conference on the Establishment of the United Nations (UN) Industrial Development Organization as a Specialized Agency. General Assembly Resolution A/RES/32/167. Available at: https://undocs.org/en/A/RES/32/167 (accessed 14 August 2018).

United Nations (UN) (1977d) Strengthening of Operational Activities in the Field of Industrial Development. General Assembly Resolution A/RES/32/165. Available at: https://undocs.org/en/A/RES/32/165 (accessed 14 August 2018).

United Nations (UN) (1977e) Target for World Food Programme Pledges for the Period 1979-1980. General Assembly Resolution A/RES/32/112. Available at: https://undocs.org/en/A/RES/32/112 (accessed 14 August 2018).

United Nations (UN) (1978a) Multilateral Trade Negotiations (110-11-11). General Assembly Resolution A/RES/33/199. Available at: https://undocs.org/en/A/RES/33/199 (accessed 14 August 2018).

United Nations (UN) (1978b) Protectionism (109-1-24). General Assembly Resolution A/RES/33/196. Available at: https://undocs.org/en/A/RES/33/196 (accessed 14 August 2018).

United Nations (UN) (1978c) Industrial Development Cooperation. General Assembly Resolution A/ RES/33/78. Available at: https://undocs.org/en/A/RES/33/78 (accessed 14 August 2018) 
United Nations (UN) (1978d) Preparations for an International Development Strategy for the Third United Nations (UN) Development Decade. General Assembly Resolution A/RES/33/193. Available at: https://undocs.org/en/A/RES/33/193 (accessed 14 August 2018).

United Nations (UN) (1979a) United Nations (UN) Conference on Science and Technology for Development. General Assembly Resolution A/RES/34/218. Available at: https://undocs.org/en/A/ RES/34/218 (accessed 14 August 2018).

United Nations (UN) (1979b) Proposals for the New International Development Strategy. General Assembly Resolution A/RES/34/211. Available at: https://undocs.org/en/A/RES/34/211 (accessed 14 August 2018).

United Nations (UN) (1979c) Official Records of the General Assembly, Thirty-Fourth Session. Available at: https://undocs.org/en/A/34/PV.109 (accessed 14 August 2018).

United Nations (UN) (1979d) Global Negotiations Relating to International Economic Cooperation for Development. General Assembly Resolution A/RES/34/138. Available at: https://undocs.org/en/A/ RES/34/138 (accessed 14 August 2018).

United Nations (UN) (1979e) Sixth Replenishment of the International Development Association and Recapitalization of the World Bank. General Assembly Resolution A/RES/34/208. Available at: https:// undocs.org/en/A/RES/34/208 (accessed 14 August 2018).

United Nations (UN) (1979f) International Monetary Reform. General Assembly Resolution A/ RES/34/216. Available at: https://undocs.org/en/A/RES/34/216 (accessed 14 August 2018).

United Nations (UN) (1979g) Multilateral Trade Negotiations (112-1-22). General Assembly Resolution A/RES/34/199. Available at: https://undocs.org/en/A/RES/34/199 (accessed 14 August 2018).

United Nations (UN) (1980a) International Development Strategy for the Third United Nations (UN) Development Decade. General Assembly Resolution A/RES/35/56. Available at: https://undocs.org/ en/A/RES/35/56 (accessed 14 August 2018).

United Nations (UN) (1980b) Official Records of the General Assembly, Thirty-Fifth Session. Available at: https://undocs.org/en/A/35/PV.84 (accessed 14 August 2018).

United Nations (UN) (1981a) United Nations (UN) Financing System for Science and Technology for Development. General Assembly Resolution A/RES/36/183. Available at: https://undocs.org/en/A/ RES/36/183 (accessed 14 August 2018).

United Nations (UN) (1981b) Industrial Development Cooperation. General Assembly Resolution A/ RES/36/182. Available at: https://undocs.org/en/A/RES/36/182 (accessed 14 August 2018).

United Nations (UN) (1981c) Global Strategy for Health for All by the Year 2000. General Assembly Resolution A/RES/36/43. Available at: https://undocs.org/en/A/RES/36/43 (accessed 14 August 2018).

United Nations (UN) (1982a) Development of the Energy Resources of Developing Countries. General Assembly Resolution A/RES/37/251. Available at: https://undocs.org/en/A/RES/37/251 (accessed 14 August 2018).

United Nations (UN) (1982b) Negative Trends in the World Economy. General Assembly Resolution A/ RES/37/203. Available at: https://undocs.org/en/A/RES/37/203 (accessed 14 August 2018).

United Nations (UN) (1982c) Immediate Measures in Favour of the Developing Countries. General Assembly Resolution A/RES/37/252. Available at: https://undocs.org/en/A/RES/37/252 (accessed 14 August 2018).

United Nations (UN) (1982d) A/37/51/Add.1. Launching of Global Negotiations on International Economic Co-Operation for Development.

United Nations (UN) (1982e) Official Records of the General Assembly, Thirty-Seventh Session. Available at: https://undocs.org/en/A/37/PV.122 (accessed 14 August 2018).

United Nations (UN) (1982f) Review of the Implementation of the Charter of Economic Rights and Duties (144-1(США)-4). General Assembly Resolution A/RES/37/204. Available at: https://undocs.org/ en/A/RES/37/204 (accessed 14 August 2018). 
United Nations (UN) (1983) Economic Measures as a Means of Political and Economic Coercion Against Developing Countries (119-19 (U.S. and Partners) -5). General Assembly Resolution A/RES/38/197. Available at: https://undocs.org/en/A/RES/38/197 (accessed 14 August 2018).

United Nations (UN) (1984) Relationship Between Disarmament and Development. General Assembly Resolution A/RES/39/160. Available at: https://undocs.org/en/A/RES/39/160 (accessed 14 August 2018).

United Nations (UN) (1984) Review of the Implementation of the Charter of Economic Rights and Duties - Review of the Implementation and Creation of a Special Review Committee (125-10 (U.S. +) 12). General Assembly Resolution A/RES/39/163. Available at: https://undocs.org/en/A/RES/39/163 (accessed 14 August 2018).

United Nations (UN) (1984) Economic Measures as a Means of Political and Economic Coercion Against Developing Countries (116-19 (U.S. +) - 6). General Assembly Resolution A/RES/39/210. Available at: https://undocs.org/en/A/RES/39/210 (accessed 14 August 2018).

United Nations (UN) (1985) Review of the Implementation of the Charter of Economic Rights and Duties - Review of the Implementation of the Charter at the 44th Session (134-1-19). General Assembly Resolution A/RES/40/182. Available at: https://undocs.org/en/A/RES/40/182 (accessed 14 August 2018).

United Nations (UN) (1985) Economic Measures as a Means of Political and Economic Coercion Against Developing Countries (128-19-7). General Assembly Resolution A/RES/40/185. Available at: https://undocs.org/en/A/RES/40/185 (accessed 14 August 2018).

United Nations (UN) (1986a) Strengthened International Economic Cooperation Aimed at Resolving External Debt Problems of Developing Countries. General Assembly Resolution A/RES/41/202. Available at: https://undocs.org/en/A/RES/41/202 (accessed 14 August 2018).

United Nations (UN) (1986b) Declaration on the Right to Development. General Assembly Resolution A/RES/41/128. Available at: https://undocs.org/en/A/RES/41/128 (accessed 14 August 2018).

United Nations (UN) (1986c) Economic Measures as a Means of Political and Economic Coercion Against Developing Countries (115-23-3). General Assembly Resolution A/RES/41/165. Available at: https://undocs.org/en/A/RES/41/165 (accessed 14 August 2018).

United Nations (UN) (1987a) Furthering International Cooperation Regarding the External Debt Problems. General Assembly Resolution A/RES/42/198. Available at: https://undocs.org/en/A/RES/42/198 (accessed 14 August 2018).

United Nations (UN) (1987b) Economic Measures as a Means of Political and Economic Coercion Against Developing Countries (128-21-5). General Assembly Resolution A/RES/42/173. Available at: https://undocs.org/en/A/RES/42/173 (accessed 14 August 2018).

United Nations (UN) (1987c) Relationship Between Disarmament and Development. General Assembly Resolution A/RES/4245. Available at: https://undocs.org/en/A/RES/42/45 (accessed 14 August 2018).

United Nations (UN) (1987d) Official Records of the General Assembly, Forty-Second Session. Preliminary Verbatim Report of the 85th Meeting. Available at: https://undocs.org/en/A/42/PV.85 (accessed 14 August 2018).

United Nations (UN) (1987e) Report of the World Commission on Environment and Development. General Assembly Resolution A/RES/42/187. Available at: https://undocs.org/en/A/RES/42/187 (accessed 14 August 2018).

United Nations (UN) (1988a) External Debt Crisis and Development: Towards a Durable Solution of the Debt Problems. General Assembly Resolution A/RES/43/198. Available at: https://undocs.org/en/A/ RES/43/198 (accessed 14 August 2018).

United Nations (UN) (1988b) Fulfilment of the Target for Official Development Assistance. General Assembly Resolution A/RES/43/197. Available at: http://www.un.org/documents/ga/res/43/a43r197.htm (accessed 13 November 2018). 
United Nations (UN) (1988c) Relationship Between Disarmament and Development. General Assembly Resolution A/RES/43/75B. Available at: https://undocs.org/en/A/RES/43/75 (accessed 14 August 2018).

United Nations (UN) (1989a) Towards a Durable Solution of External Debt Problems. General Assembly Resolution A/RES/44/205. Available at: https://undocs.org/en/A/RES/44/205 (accessed 14 August 2018).

United Nations (UN) (1989b) Economic Measures as a Means of Political and Economic Coercion Against Developing Countries (118-23 (CWA+)-2). General Assembly Resolution A/RES/44/215. Available at: https://undocs.org/en/A/RES/44/215 (accessed 14 August 2018).

United Nations (UN) (1989c) Review of the Implementation of the Charter of Economic Rights and Duties - On the Need to Implement the Charter (131-1-23). General Assembly Resolution A/RES/44/170. Available at: https://undocs.org/en/A/RES/44/170 (accessed 14 August 2018).

United Nations (UN) (1989d) Relationship Between Disarmament and Development. General Assembly Resolution A/RES/44/116L. Available at: https://undocs.org/en/A/RES/44/116 (accessed 14 August 2018).

United Nations (UN) (1989e) United Nations (UN) Conference on Environment and Development. General Assembly Resolution A/RES/44/228. Available at: https://undocs.org/en/A/RES/44/228 (accessed 14 August 2018).

United Nations (UN) (1990a) International Development Strategy for the Fourth United Nations (UN) Development Decade. General Assembly Resolution A/RES/45/199. Available at: https://undocs.org/ en/A/RES/45/199 (accessed 14 August 2018).

United Nations (UN) (1990b) International Debt Crisis and Development: Enhanced International Cooperation Towards a Durable Solution to the External Debt Problems of Developing Countries. General Assembly Resolution A/RES/45/214. Available at: https://undocs.org/en/A/RES/45/214 (accessed 14 August 2018).

United Nations (UN) (1991a) Impact of the Recent Evolution of East-West Relations on the Growth of the World Economy, in Particular on the Economic Growth and Development of the Developing Countries, As Well As on International Economic Cooperation. General Assembly Resolution A/RES/46/202. Available at: https://undocs.org/en/A/RES/46/202 (accessed 14 August 2018).

United Nations (UN) (1991b) International Debt Crisis and Development Enhanced International Cooperation Towards a Durable Solution to the External Debt Problems of Developing Countries. General Assembly Resolution A/RES/46/148. Available at: https://undocs.org/en/A/RES/46/148 (accessed 14 August 2018).

United Nations (UN) (1992a) Impact of the Recent Evolution of the Economies in Transition on the Growth of the World Economy, in Particular on the Economic Growth and Development of the Developing Countries, As Well As on International Economic Cooperation. General Assembly Resolution A/ RES/47/175. Available at: https://undocs.org/en/A/RES/47/175 (accessed 14 August 2018).

United Nations (UN) (1992b) International Debt Crisis and Development Enhanced International Cooperation Towards a Durable Solution to the External Debt Problems of Developing Countries. General Assembly Resolution A/RES/47/198. Available at: https://undocs.org/en/A/RES/47/198 (accessed 14 August 2018).

United Nations (UN) (1992c) Development Agenda. General Assembly Resolution A/RES/47/181. Available at: https://undocs.org/en/A/RES/47/181 (accessed 14 August 2018).

United Nations (UN) (1992d) Rio Declaration on Environment and Development A/CONF.151/26. United Nations Conference on Environment and Development. Available at: http://www.un-documents. net/rio-dec.htm (accessed 14 August 2018).

United Nations (UN) (1994) Enhanced International Cooperation Towards a Durable Solution to the External Debt Problems of Developing Countries. General Assembly Resolution A/RES/49/94. Available at: https://undocs.org/en/A/RES/49/94 (accessed 14 August 2018). 
United Nations (UN) (1995a) Enhancing International Cooperation Towards a Durable Solution to the External Debt Problems of Developing Countries. General Assembly Resolution A/RES/50/92. Available at: https://undocs.org/en/A/RES/50/92 (accessed 14 August 2018).

United Nations (UN) (1995b) International Trade and Development. General Assembly Resolution A/ RES/50/95. Available at: https://undocs.org/en/A/RES/50/95 (accessed 14 August 2018).

United Nations (UN) (1996a) Global Financing Integration and Strengthening Collaboration Between the United Nations (UN) and the Bretton Woods Institutions. General Assembly Resolution A/ RES/51/166. Available at: https://undocs.org/en/A/RES/51/166 (accessed 14 August 2018).

United Nations (UN) (1996b) Suppression of the Use of Economic Coercive Measures as a Means of Exerting Political and Economic Pressure (56-4 (Israel, Micronesia, Uzbekistan, and the U.S.) -76). General Assembly Resolution A/RES/51/22. Available at: https://undocs.org/en/A/RES/51/22 (accessed 14 August 2018).

United Nations (UN) (1997a) Unilateral Economic Measures as a Means of Political and Economic Coercion of Developing Countries (109-1 (U.S.) -50). General Assembly Resolution A/RES/52/181. Available at: https://undocs.org/en/A/RES/53/10 (accessed 14 August 2018).

United Nations (UN) (1997b) Global Financing Flows and Their Impact on the Developing Countries. General Assembly Resolution A/RES/52/180. Available at: https://undocs.org/en/A/RES/52/180 (accessed 14 August 2018).

United Nations (UN) (1997c) Agenda for Development. General Assembly Resolution A/RES/51/240. Available at: https://undocs.org/en/A/RES/51/240 (accessed 14 August 2018).

United Nations (UN) (1998a) Suppression of the Use of Economic Coercive Measures as a Means of Exerting Political and Economic Pressure (80-2 (U.S. and Israel) -67). General Assembly Resolution A/ RES/53/10. Available at: (accessed 14 August 2018).

United Nations (UN) (1998b) the Financial Crisis and Its Impact on Growth and Development, Especially in the Developing Countries. General Assembly Resolution A/RES/53/172. Available at: https:// undocs.org/en/A/RES/53/172 (accessed 14 August 2018).

United Nations (UN) (1998c) International Trade and Development. General Assembly Resolution A/ RES/53/170. Available at: https://undocs.org/en/A/RES/53/170 (accessed 14 August 2018).

United Nations (UN) (1999a) Unilateral Economic Measures as a Means of Political and Economic Coercion of Developing Countries (94-3-43). General Assembly Resolution A/RES/54/200. Available at: https://undocs.org/en/A/RES/54/200 (accessed 14 August 2018).

United Nations (UN) (1999b) Official Records of the General Assembly, Fifty-Fourth Session. Available at: https://undocs.org/en/A/54/PV.87 (accessed 14 August 2018).

United Nations (UN) (2000a) Towards Strengthened and Stable International Financial Architecture Responsive to the Priorities of Growth and Development, Especially in Developing Countries, and to the Promotion of Economic and Social Equity. General Assembly Resolution A/RES/55/186. Available at: https://undocs.org/en/A/RES/55/186 (accessed 14 August 2018).

United Nations (UN) (2000b) Official Records of the General Assembly, Fifty-Fifth Session. Available at: https://undocs.org/en/A/55/PV.87 (accessed 14 August 2018).

United Nations (UN) (2000c) Implementation of the Commitments and Policies Agreed Upon in the Declaration on International Economic Cooperation, in Particular the Revitalization of Economic Growth and Development of the Developing Countries, and Implementation of the International Development Strategy for the Fourth United Nations (UN) Development Decade. General Assembly Resolution A/RES/55/190. Available at: https://undocs.org/en/A/RES/55/190 (accessed 14 August 2018).

United Nations (UN) (2000d) United Nations (UN) Millennium Declaration. General Assembly Resolution A/RES/55/2. Available at: https://undocs.org/en/A/RES/55/2 (accessed 14 August 2018). 


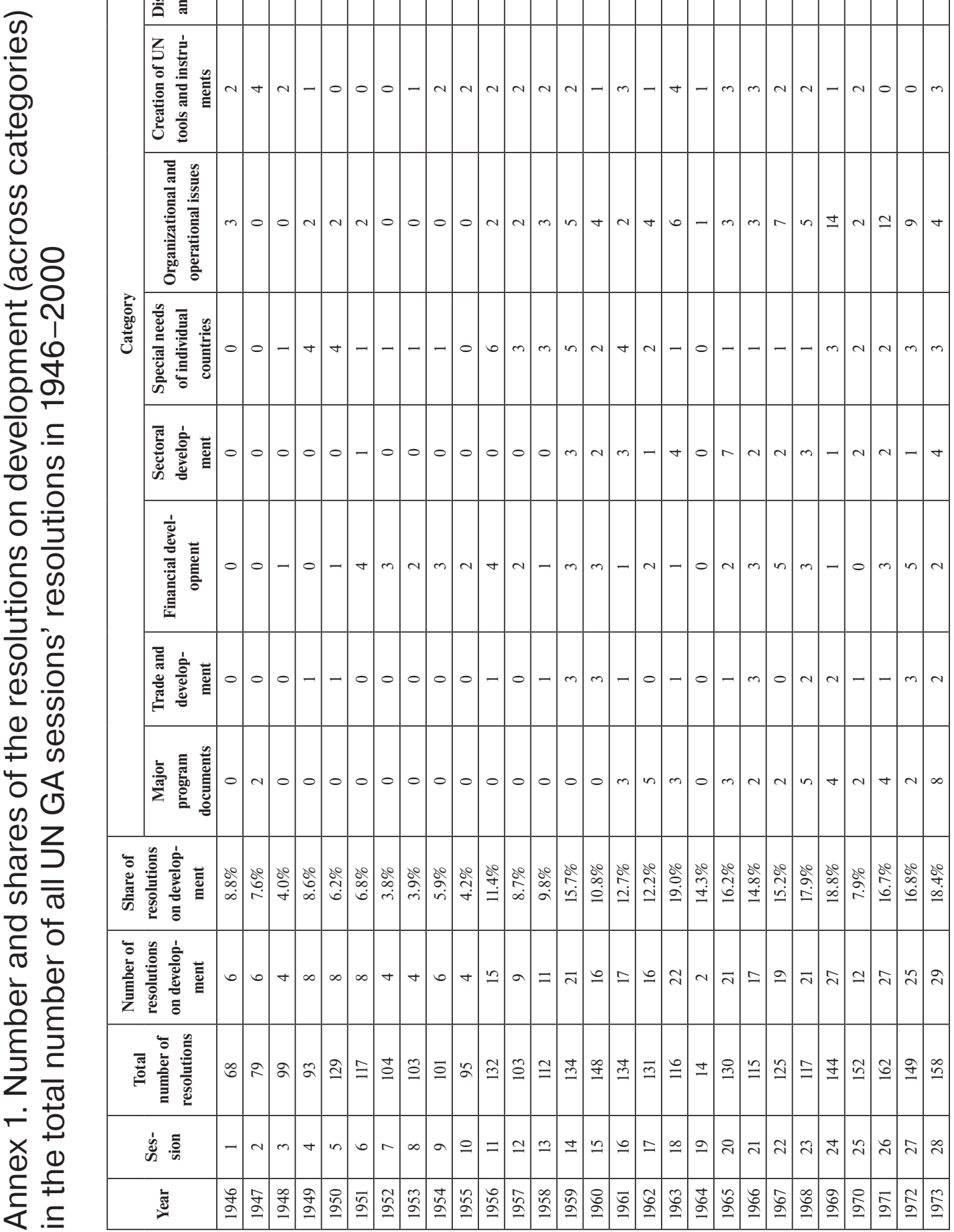

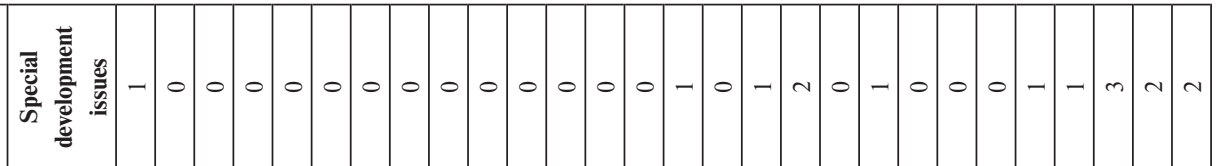

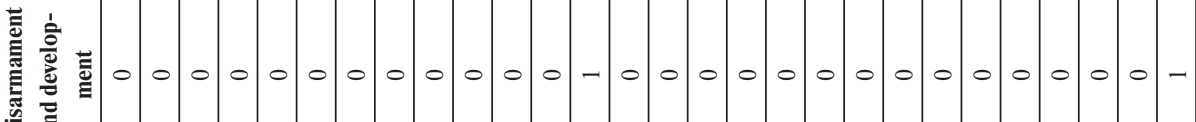
总 흥

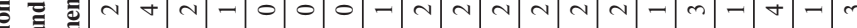




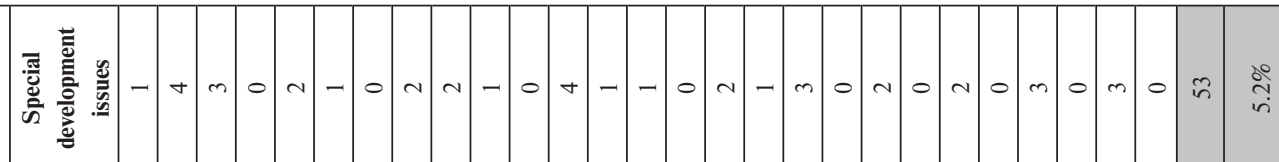

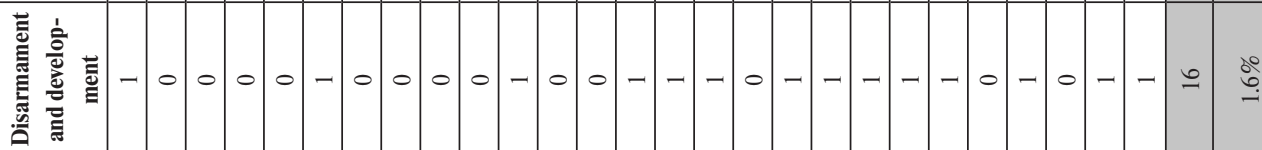

学 竞

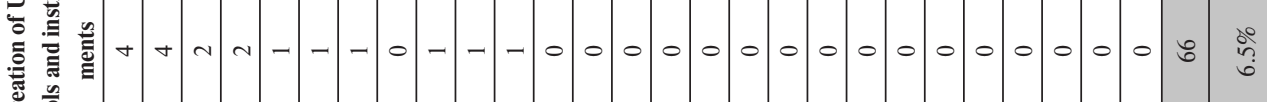

5:

플

离

कू

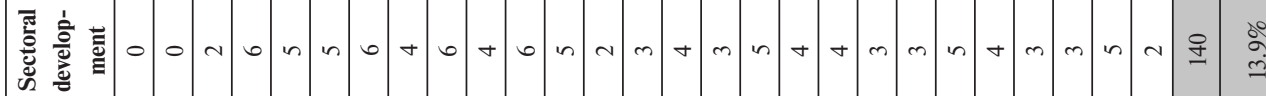

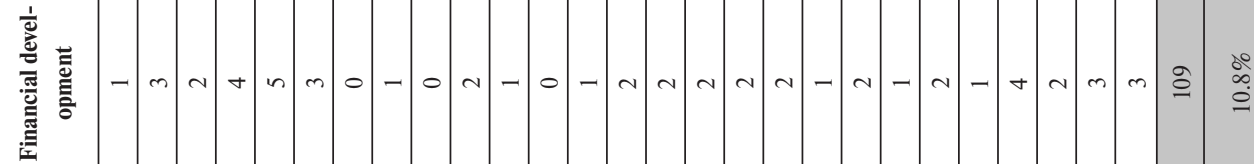

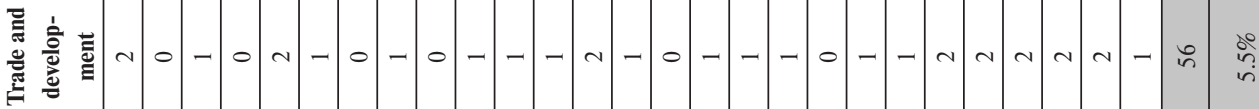

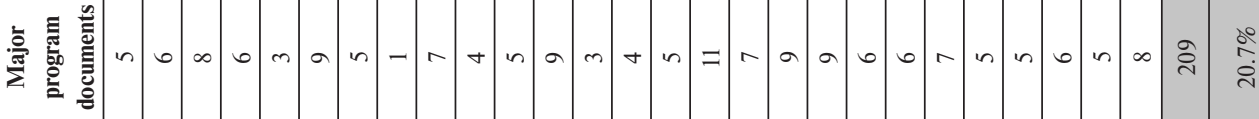

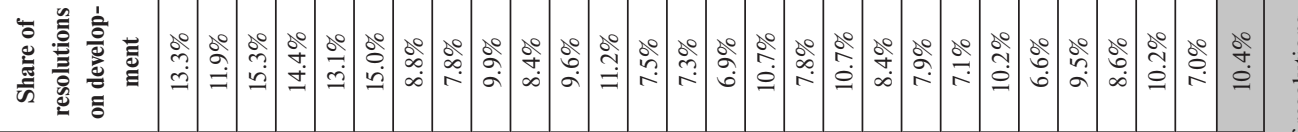

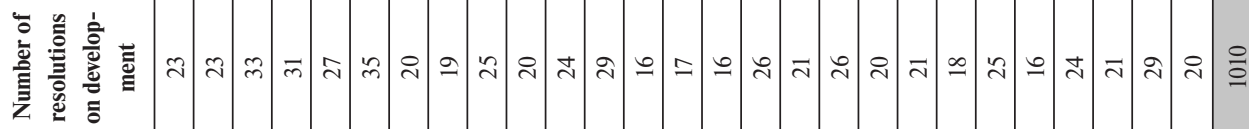

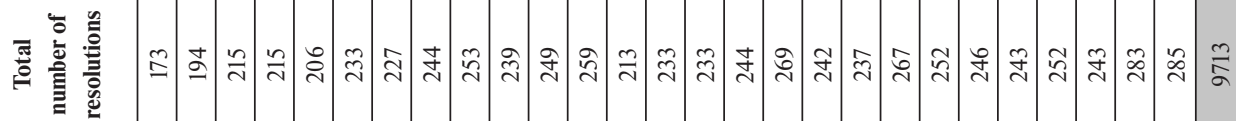

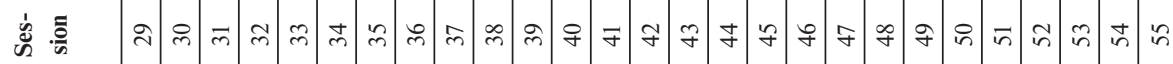

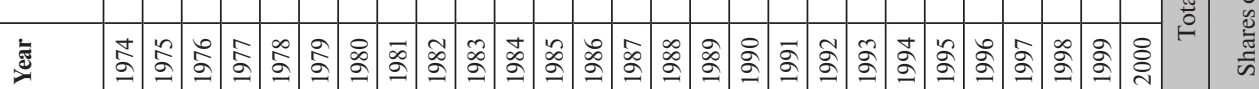




\title{
Первые десятилетия сотрудничества для развития. Участники, достижения и трудности 1
}

\author{
М.В. Ларионова, Е.А. Сафонкина
}

\begin{abstract}
Ларионова Марина Владимировна - д.полит.н., директор Центра исследований международных институтов (ЦИМИ) Российской академии народного хозяйства и государственной службы при Президенте РФ (РАНХиГС); профессор факультета мировой экономики и мировой политики Национального исследовательского университета «Высшая школа экономики»; Российская Федерация, 119034, Москва, Пречистенская наб., д. 11; E-mail: larionova-mv@ranepa.ru
\end{abstract}

Сафонкина Елизавета Андреевна - н.с. Центра исследований международных институтов (ЦИМИ) Российской академии народного хозяйства и государственной службы при Президенте РФ (РАНХиГС); Российская Федерация, 119034, Москва, Пречистенская наб., д. 11; E-mail: safonkina-ea@ranepa.ru

Принятые в 2015 г. Цели устойчивого развития (ЦУР) до 2030 г. являются мировым ориентиром для развитых и развивающихся государств в выработке национальной политики и осуществлении международного сотрудничества с целью совместной борьбы с глобальными вызовами. ЦУР опираются на результаты работы всех участников глобального партнерства в целях развития, основы которого были заложены ООН еще в ХХ в. Статья посвящена эволюции системы международного сотрудничества в щелях развития, складывавшейся в рамках ООН в период с 1946 по 2000 г. (год принятия Декларации тысячелетия). Исследование опирается на анализ текстов резолюций и официальных отчетов ключевых органов ООН, прежде всего Генеральной Ассамблеи и Экономического и Социального Совета ООН (ЭКОСОС). Контент-анализ записей прений позволяет выявить официальные позиции делегаций, интересы и противоречия, скрывающиеся за сухими формулировками резолюций.

Четыре десятилетия развития завершились принятием Декларации тысячелетия ООН. На каждом из этапов эволюции системы были достижения и проблемы. С первых сессий ГА и ЭКОСОС формировались основные принципы, механизмы и направления сотрудничества. Уже в конце 1940-х начался процесс создания инструментов содействия развитию. Созданы Всемирная организация здравоохранения, Детский фонд ООН, Продовольственная и сельскохозяйственная организация ООН, Расширенная программа технической помощи, региональные экономические комиссии, Специальный Фонд ООН. На первом этапе становления инструментов сотрудничества для развития утвердилась монополия доллара. Значительное место в резолюциях о развитии занимали вопросы развития мирового рынка, улучшения условий торговли для развития. В 1960 г. впервые сформулирована задача увеличения предоставления международной помощи и капитала до $1 \%$ национального дохода экономически развитых стран.

Период 1961-1970 гг. ознаменовался принятием Программы международного экономического сотрудничества - первой «Декады развития» ООН и Мировой продовольственной программы, созданием ООН по промышленному развитию (ЮНИДО), Конференции ООН по торговле и развитию (ЮНКТАД) и ПРООН, разработкой Международной стратегии развития на второе десятилетие развития ООН. В связи с задачей решения проблемы роста задолженности и обеспечения международной ликвидности в повестку дня вошли вопросы реформы международной валютной системы.

Ключевые события второго десятилетия включают постепенную интеграцию проблем развития и окружающей среды; усилия по преодолению международного валютного кризиса, обеспечению ликвидности, облегчению нарастающего бремени задолженности развивающихся стран; рост целевых заданий по Программе развития ООН, Мировой продовольственной программе и специальным фондам; решения о разработке и принятии Хартии экономических прав и обязанностей государств; усилия по реализации принципа дифференцированного отношения к развивающимся странам в рамках ГАТТ; подготовку и принятие Межжународной стратегии

${ }^{1}$ Статья поступила в редакцию в августе 2018 г.

Исследование выполнено при финансовой поддержке РФФИ в рамках проекта проведения научных исследований «Эволюция многостороннего сотрудничества по содействию развитию под эгидой ООН: от декады развития к Целям устойчивого развития (ЦУР)», проект № 18-014-00008. 
на третье десятилетие развития ООН; неудачную попытку запуска глобальных переговоров по перестройке международной экономической системы.

Третье десятилетие знаменательно усилиями по укреплению научно-технического, промышленного потенциала, развитию энергетических ресурсов развивающихся стран, принятием Глобальной стратегии обеспечения здоровья для всех к 2000 г., принятием Декларации о праве на развитие, подготовкой и принятием Международной стратегии развития на четвертое десятилетие развития. Достижением стала переориентации сотрудничества в сторону моделей устойчивого развития. Замедление темпов экономического роста, неустойчивость валют, усиление протекционизма, структурные диспропорции в мировой экономике требовали системного решения по реформе международной валютной системы, однако глобальные переговоры зашли в тупик, поскольку позиция «семерки» о гарантии независимости специализированных учреждений создавала непреодолимое препятствие в поиске комплексных решений перестройки международных экономических отношений. Этот подход определил ригидность системы на долгие годы и ее неспособность предотвратить кризисы 1998 и 2008 г2.

В четвертом десятилетии важнейшими вехами в сотрудничестве для развития стало принятие 20 июня 1997 г. Повестки дня для развития и Декларации тысячелетия Организации Объединенных Наций.

Таким образом, во второй половине ХХ в. международное сообщество прошло длинный путь формирования сотрудничества для развития. ООН стала колыбелью и двигателем этого процесса, основным фактором его успеха. Безусловные достижения 55 лет коллективных усилий включают последовательную консолидацию программного фундамента сотрудничества от первой Декады развития к Целям развития тысячелетия; совершенствование инструментов обзора и оценки результатов программ; интеграцию вопросов развития и окружающей среды; а также создание ключевых инструментов и рост финансирования для развития. Задача формирования внешних условий развития на основе перестройки международной экономической системы с учетом интересов развивающихся стран не была реализована. Системные проблемы международной валютной и торговой системы остались в наследство ХХІ в.

Ключевые слова: сотрудничество для развития; ООН; Генеральная Ассамблея; ЭКОСОС; ПРООН; международные финансовые учреждения

Для цитирования: Ларионова М.В., Сафонкина Е.А. (2018) Первые десятилетия сотрудничества для развития. Участники, достижения и трудности // Вестник международных организаций. Т. 13. № 4. С. 96-136 (на русском и английском языках). DOI: 10.17323/1996-7845-2018-04-05.

\section{Источники}

Alonso J.A., Glennie J. (2015) What Is Development Cooperation? ECOSOC Development Cooperation Forum Policy Briefs No. 1. Режим доступа: http://www.un.org/en/ecosoc/newfunct/pdf15/2016_dcf_policy_ brief_no.1.pdf (дата обращения: 14.08.2018).

Group of 7 (1982) Declaration of the Seven Heads of State and Government and Representatives of the European Communities. Versailles, 4-6 June. Режим доступа: http://www.g8.utoronto.ca/summit/1982versailles/ communique.html (дата обращения: 14.08.2018).

Hufbauer G.C., Schott J.J., Eliot K.A., Oegg B. (2009) Economic Sanctions Reconsidered. 3rd edition. Washington DC: Peterson Institute for International Economics. Режим доступа: https://piie.com/publications/ chapters_preview/4075/01iie4075.pdf (дата обращения: 14.08.2018).

Shumilov V.M. (2005) International Public Economic Law. Moscow: International Relations

United Nations (UN) (1946) Agreements with Specialized Agencies. General Assembly Resolution A/RES/50 (1). Режим доступа: https://undocs.org/en/A/RES/50(I) (дата обращения: 14.08.2018).

United Nations (UN) (1947a) Agreements with Specialized Agencies. General Assembly Resolution A/ RES/124 (II). Режим доступа: https://undocs.org/en/A/RES/124(II) (дата обращения: 14.08.2018).

United Nations (UN) (1947b) Reports on World Economic Conditions and Trends. General Assembly Resolution A/RES/118 (II). Режим доступа: https://undocs.org/en/A/RES/118(II) (дата обращения: 14.08.2018).

United Nations (UN) (1947c) Implementation of Recommendations on Economic and Social Matters. General Assembly Resolution A/RES/119 (II). Режим доступа: https://undocs.org/en/A/RES/119(II) (дата обращения: 14.08.2018). 
United Nations (UN) (1948a) Economic Development of Under-Developed Countries. General Assembly Resolution A/RES/198 (III). Режим доступа: https://undocs.org/en/A/RES/198(III) (дата обращения: 14.08.2018).

United Nations (UN) (1948b) Technical Assistance for Economic Development. General Assembly Resolution A/RES/200 (III). Режим доступа: https://undocs.org/en/A/RES/200(III) (дата обращения: 14.08.2018).

United Nations (UN) (1949) Economic Development and International Economic and Commercial Policy. General Assembly Resolution A/RES/307 (IV). Режим доступа: https://undocs.org/en/A/RES/307(IV) (дата обращения: 14.08.2018).

United Nations (UN) (1950) Financing Economic Development of Under-Developed Countries. General Assembly Resolution A/RES/400 (V). Режим доступа: https://undocs.org/en/A/RES/400(V) (дата обращения: 14.08.2018).

United Nations (UN) (1952a) Financing of Economic Development of Under-Developed Countries. General Assembly Resolution A/RES/520 (VI). Режим доступа: https://undocs.org/en/A/RES/520(VI) (дата обращения: 14.08.2018).

United Nations (UN) (1952b) Official Records of the General Assembly, Sixth Session. Режим доступа: http://www.un.org/en/ga/search/view_doc.asp?symbol=A/PV.360 (дата обращения: 14.08.2018).

United Nations (UN) (1953) A. Economic Development of Underdeveloped Countries. General Assembly Resolution A/RES/724(VIII). Режим доступа: http://www.un.org/en/ga/search/view_doc.asp?symbol=A/ RES/724(VIII) (дата обращения: 14.08.2018).

United Nations (UN) (1954a) Question of the Establishment of an International Finance Corporation. General Assembly Resolution A/RES/823(IX). Режим доступа: http://www.un.org/en/ga/search/view_doc. asp?symbol=A/RES/823(IX) (дата обращения: 14.08.2018).

United Nations (UN) (1954b) Question of the Establishment of a Special United Nations (UN) Fund for Economic Development. General Assembly Resolution A/RES/822(IX). Режим доступа: http://www.un.org/en/ ga/search/view_doc.asp?symbol=A/RES/822(IX) (дата обращения: 14.08.2018).

United Nations (UN) (1955) Confirmation of Allocation of Funds Under the Expanded Programme of Technical Assistance. General Assembly Resolution A/RES/994 (X). Режим доступа: https://undocs.org/en/A/ RES/994(Х) (дата обращения: 14.08.2018).

United Nations (UN) (1956a) Official Records of the General Assembly, Eleventh Session. Режим доступа: https://undocs.org/en/A/PV.632 (дата обращения: 14.08.2018).

United Nations (UN) (1956b) Currency Utilization. General Assembly Resolution A/RES/1021 (XI). Режим доступа: https://undocs.org/en/A/RES/1021(XI) (дата обращения: 14.08.2018).

United Nations (UN) (1957a) Financing of Economic Development. General Assembly Resolution A/ RES/1219 (XII). Режим доступа: https://undocs.org/en/A/RES/1219(XII) (дата обращения: 14.08.2018).

United Nations (UN) (1957b) Official Records of the General Assembly, Twelfth Session. Режим доступа: https://undocs.org/en/A/PV.730 (дата обращения: 14.08.2018).

United Nations (UN) (1957c) Industrialization of Underdeveloped Countries. General Assembly Resolution A/RES/1033 (XI). Режим доступа: https://undocs.org/en/A/RES/1033(XI) (дата обращения: 14.08.2018).

United Nations (UN) (1957d) Development of International Economic Cooperation and the Expansion of International Trade. General Assembly Resolution A/RES/1027 (XI). Режим доступа: https://undocs.org/ en/A/RES/1027(XI) (дата обращения: 14.08.2018).

United Nations (UN) (1958a) Establishment of the Special Fund. General Assembly Resolution A/RES/1240 (XIII). Режим доступа: https://undocs.org/en/A/RES/1240(XIII) (дата обращения: 14.08.2018).

United Nations (UN) (1958b). Official Records of the General Assembly, Thirteenth Session. Режим доступа: https://undocs.org/en/A/PV.776. (дата обращения: 14.08.2018).

United Nations (UN) (1959a) Confirmation of Allocation of Funds for the Expanded Programme of Technical Assistance in 1960. General Assembly Resolution A/RES/1432 (XIV). Режим доступа: https://undocs.org/ en/A/RES/1432(XIV) (дата обращения: 14.08.2018).

United Nations (UN) (1959b) Progress and Operations of the Special Fund. General Assembly Resolution A/ RES/1382 (XIV). Режим доступа: https://undocs.org/en/A/RES/1382(XIV) (дата обращения: 14.08.2018). 
United Nations (UN) (1959c) Strengthening and Development of the World Market and Improvement of the Trade Conditions of the Economically Less Developed Countries. General Assembly Resolution A/RES/1421 (XIV). Режим доступа: https://undocs.org/en/A/RES/1421(XIV) (дата обращения: 14.08.2018).

United Nations (UN) (1959d) International Measures to Assist in Offsetting Fluctuation in Commodity Prices. General Assembly Resolution A/RES/1423 (XIV). Режим доступа: https://undocs.org/en/A/RES/1423(XIV) (дата обращения: 14.08.2018).

United Nations (UN) (1959e) Official Records of the General Assembly, Fourteenth Session. Режим доступа: https://undocs.org/en/A/PV.846 (дата обращения: 14.08.2018).

United Nations (UN) (1960a) Contributions to the Special Fund and to the Expanded Programme of Technical Assistance. General Assembly Resolution A/RES/1529 (XV). Режим доступа: https://undocs.org/en/A/ RES/1529(XV) (дата обращения: 14.08.2018).

United Nations (UN) (1960b) Accelerated Flow of Capital and Technical Assistance to the Developing Countries. General Assembly Resolution A/RES/1522 (XV). Режим доступа: https://undocs.org/en/A/ RES/1522(XV) (дата обращения: 14.08.2018).

United Nations (UN) (1960c) Establishment of the United Nations (UN) Capital Development Fund. General Assembly Resolution A/RES/1521 (XV). Режим доступа: https://undocs.org/en/A/RES/1521(XV) (дата обращения: 14.08.2018).

United Nations (UN) (1960d) Improvements of the Terms of Trade Between the Industrial and the Underdeveloped Countries. General Assembly Resolution A/RES/1520(XV). Режим доступа: https://undocs.org/ en/A/RES/1520(XV) (дата обращения: 14.08.2018).

United Nations (UN) (1960e) Financing of Economic Development of Less Developed Countries Through Long-Term Loans and in Other Advantageous Ways, and Ensuring an Increasing Share in World Trade for Their Products. General Assembly Resolution A/RES/1524 (XV). Режим доступа: https://undocs.org/en/A/ $\mathrm{RES} / 1524(\mathrm{XV})$ (дата обращения: 14.08.2018)

United Nations (UN) (1960f) Official Records of the General Assembly, Fifteenth Session. Режим доступа: https://undocs.org/en/A/PV.908 (дата обращения: 14.08.2018).

United Nations (UN) (1960g) Provision of Food Surpluses to Food-Deficient Peoples Through the United Nations (UN) System. General Assembly Resolution A/RES/1496 (XV). Режим доступа: https://undocs.org/ en/A/RES/1496(XV) (дата обращения: 14.08.2018).

United Nations (UN) (1961a) United Nations (UN) Development Decade - A Programme for International Economic Cooperation. General Assembly Resolution A/RES/1710 (XVI). Режим доступа: https://undocs. org/en/A/RES/1710(XVI) (дата обращения: 14.08.2018).

United Nations (UN) (1961b) Reaffirmation of General Assembly Resolution 1522 (XV) On the Accelerated Flew of Capital and Technical Assistance to the Developing Countries. General Assembly Resolution A/ RES/1711 (XVI). Режим доступа: https://undocs.org/en/A/RES/1711(XVI) (дата обращения: 14.08.2018).

United Nations (UN) (1961c) World Food Programme. General Assembly Resolution A/RES/1714 (XVI). Режим доступа: https://undocs.org/en/A/RES/1714(XVI) (дата обращения: 14.08.2018).

United Nations (UN) (1961d) International Trade as the Primary Instrument for Economic Development. General Assembly Resolution A/RES/1707 (XVI). Режим доступа: https://undocs.org/en/A/RES/1707(XVI) (дата обращения: 14.08.2018).

United Nations (UN) (1963a) Activities in the Field of Industrial Development. General Assembly Resolution A/RES/1940 (XVIII). Режим доступа: https://undocs.org/en/A/RES/1940(XVIII) (дата обрашения: 14.08.2018).

United Nations (UN) (1963b) Official Records of the General Assembly, Eighteenth Session. Режим доступа: https://undocs.org/en/A/PV.1256 (дата обращения: 14.08.2018).

United Nations (UN) (1965a) Consolidation of the Special Fund and the Expanded Programme of Technical Assistance in a United Nations (UN) Development Programme. General Assembly Resolution A/RES/2029 (XX). Режим доступа: https://undocs.org/en/A/RES/2029(XX) (дата обращения: 14.08.2018).

United Nations (UN) (1965b) Consolidation of the Special Fund and the Expanded Programme of Technical Assistance in a United Nations (UN) Development Programme. General Assembly Resolution A/RES/2029 (XX). Режим доступа: https://undocs.org/en/A/RES/2029(XX) (дата обращения: 14.08.2018). 
United Nations (UN) (1965c) Establishment of the United Nations (UN) Organizations for Industrial Development. General Assembly Resolution A/RES/2089 (XX). Режим доступа: https://undocs.org/en/A/ RES/2089(XX) (дата обращения: 14.08.2018).

United Nations (UN) (1965d) Establishment of the United Nations (UN) Conference on Trade and Development as an Organ of the General Assembly. General Assembly Resolution A/RES/1995 (XIX). Режим доступа: https://undocs.org/en/A/RES/1995(XIX) (дата обращения: 14.08.2018).

United Nations (UN) (1966a) United Nations (UN) Industrial Development Organization. General Assembly Resolution A/RES/2152 (XXI). Режим доступа: https://undocs.org/en/A/RES/2152(XXI) (дата обращения: 14.08.2018).

United Nations (UN) (1966b) General Review of the Programmes and Activities in the Economic, Social, Technical Cooperation and Related Fields of the United Nations (UN), the Specialized Agencies, the International Atomic Energy Agency, the United Nations (UN) Children's Fund and All Other Institutions and Agencies Related to the United Nations (UN) System. General Assembly Resolution A/RES/2188 (XXI). Режим доступа: https://undocs.org/en/A/RES/2188(XXI) (дата обращения: 14.08.2018).

United Nations (UN) (1966c) United Nations (UN) Development Decade. General Assembly Resolution A/ RES/2218 (XXI). Режим доступа: https://undocs.org/en/A/RES/2218(XXI) (дата обращения: 14.08.2018).

United Nations (UN) (1966d) World Social Situation. General Assembly Resolution A/RES/2215 (XXI). Режим доступа: https://undocs.org/en/A/RES/2215(XXI) (дата обращения: 14.08.2018).

United Nations (UN) (1966e) External Financing of Economic Development of Developing Countries. General Assembly Resolution A/RES/2169 (XXI). Режим доступа: https://undocs.org/en/A/RES/2169(XXI) (дата обращения: 14.08.2018).

United Nations (UN) (1966f) Flow of External Resources to Developing Countries. General Assembly Resolution A/RES/2170 (XXI). Режим доступа: https://undocs.org/en/A/RES/2170(XXI) (дата обращения: 14.08.2018).

United Nations (UN) (1966g) International Monetary Reform. General Assembly Resolution A/RES/2208 (XXI). Режим доступа: https://undocs.org/en/A/RES/2208(XXI) (дата обращения: 14.08.2018).

United Nations (UN) (1967) United Nations (UN) Capital Development Fund. General Assembly Resolution A/RES/2321 (XXII). Режим доступа: https://undocs.org/en/A/RES/2321(XXII) (дата обращения: 14.08.2018).

United Nations (UN) (1968a) International Monetary Reform. General Assembly Resolution A/RES/2461 (XXIII). Режим доступа: https://undocs.org/en/A/RES/2461(XXIII) (дата обращения: 14.08.2018).

United Nations (UN) (1968b) Problems of the Human Environment. General Assembly Resolution A/ RES/2398 (XXIII). Режим доступа: https://undocs.org/en/A/RES/2398(XXIII) (дата обращения: 14.08.2018).

United Nations (UN) (1969a) Target for Pledges to the World Food Programme for the Period 1971-1972. General Assembly Resolution A/RES/2527 (XXIV). Режим доступа: https://undocs.org/en/A/RES/2527(XXIV) (дата обращения: 14.08.2018).

United Nations (UN) (1969b) International Monetary Reform. General Assembly Resolution A/RES/2565 (XXIV). Режим доступа: https://undocs.org/en/A/RES/2565(XXIV) (дата обращения: 14.08.2018).

United Nations (UN) (1969c) Declaration on Social Progress and Development. General Assembly Resolution A/RES/2542 (XXIV). Режим доступа: https://undocs.org/en/A/RES/2542(XXIV) (дата обращения: 14.08.2018).

United Nations (UN) (1969d) Declaration on Social Progress and Development. General Assembly Resolution A/RES/2542 (XXIV). Режим доступа: https://undocs.org/en/A/RES/2542(XXIV) (дата обращения: 14.08.2018).

United Nations (UN) (1970a) Official Records of the General Assembly, Twenty-Fifth Session. Режим доступа: https://undocs.org/en/A/PV.1918 (дата обращения: 14.08.2018).

United Nations (UN) (1970b) United Nations (UN) Conference on the Human Environment. General Assembly Resolution A/RES/2657 (XXV). Режим доступа: https://undocs.org/en/A/RES/2657(XXV) (дата обращения: 14.08.2018)

United Nations (UN) (1970c) International Development Strategy for the Second United Nations (UN) Development Decade. General Assembly Resolution A/RES/2626 (XXV). Режим доступа: https://undocs.org/ en/A/RES/2626(XXV) (дата обращения: 14.08.2018). 
United Nations (UN) (1971a) Official Records of the General Assembly, Twenty-Sixth Session. Режим доступа: https://undocs.org/en/A/PV.2026 (дата обращения: 14.08.2018).

United Nations (UN) (1971b) Development and Environment. General Assembly Resolution A/RES/2849 (XXVI). Режим доступа: https://undocs.org/en/A/RES/2849(XXVI) (дата обращения: 14.08.2018).

United Nations (UN) (1971c) International Currency Situation. General Assembly Resolution A/RES/2807 (XXVI). Режим доступа: https://undocs.org/en/A/RES/2807(XXVI) (дата обращения: 14.08.2018).

United Nations (UN) (1972a) Development and Environment. General Assembly Resolution A/RES/3002 (XXVII). Режим доступа: https://undocs.org/en/A/RES/3002(XXVII) (дата обращения: 14.08.2018).

United Nations (UN) (1972b) External Debt Servicing by the Developing Countries. General Assembly Resolution A/RES/3039 (XXVII). Режим доступа: https://undocs.org/en/A/RES/3039(XXVII) (дата обращения: 14.08.2018).

United Nations (UN) (1972c) Multilateral Trade Negotiations. General Assembly Resolution A/RES/3040 (XXVII). Режим доступа: https://undocs.org/en/A/RES/3040(XXVII) (дата обращения: 14.08.2018).

United Nations (UN) (1972d) Financial Resources of the United Nations (UN) Development Programme. General Assembly Resolution A/RES/2973 (XXVII). Режим доступа: https://undocs.org/en/A/ RES/2973(XXVII) (дата обращения: 14.08.2018).

United Nations (UN) (1973a) First Biennial Over-All Review and Appraisal of Progress in the Implementation of the International Development Strategy for the Second United Nations (UN) Development Decade. General Assembly Resolution A/RES/3176 (XXVIII). Режим доступа: https://undocs.org/en/A/RES/3176(XXVIII) (дата обращения: 14.08.2018).

United Nations (UN) (1973b) Reform of International Monetary System. General Assembly Resolution A/ RES/3084 (XXVIII). Режим доступа: https://undocs.org/en/A/RES/3084(XXVIII) (дата обращения: 14.08.2018).

United Nations (UN) (1973c) Reduction of the Military Budgets of States Permanent Members of the Security Council by 10 Per Cent and Utilization of Part of the Funds Thus Saved to Provide Assistance to Developing Countries. General Assembly Resolution A/RES/3093. Режим доступа: https://undocs.org/en/A/ RES/3093(XXVIII) (дата обращения: 14.08.2018).

United Nations (UN) (1974) United Nations (UN) Special Fund. General Assembly Resolution A/RES/3356 (XXIX). Режим доступа: https://undocs.org/en/A/RES/3356(XXIX) (дата обращения: 14.08.2018).

United Nations (UN) (1975a) Fifth Replenishment of the International Development Association. General Assembly Resolution A/RES/3387 (XXX). Режим доступа: https://undocs.org/en/A/RES/3387(XXX) (дата обращения: 14.08.2018).

United Nations (UN) (1975b) United Nations (UN) Special Fund. General Assembly Resolution A/RES/3460 (XXX). Режим доступа: https://undocs.org/en/A/RES/3460(XXX) (дата обращения: 14.08.2018).

United Nations (UN) (1975c) Establishment of an International Fund for Agricultural Development. General Assembly Resolution A/RES/3503 (XXX). Режим доступа: https://undocs.org/en/A/RES/3503(XXX) (дата обращения: 14.08.2018).

United Nations (UN) (1976a) Recapitalization of the International Bank for Reconstruction and Development and Replenishment of the International Development Association. General Assembly Resolution A/ RES/31/181. Режим доступа: https://undocs.org/en/A/RES/31/181 (дата обращения: 14.08.2018).

United Nations (UN) (1976b) Official Records of the General Assembly, Thirty-First Session. Режим доступа: https://undocs.org/en/A/31/PV.106 (дата обращения: 14.08.2018).

United Nations (UN) (1976c) Ways and Means of Accelerated the Transfer of Real Resources to Developing Countries on a Predictable, Assured and Continuous Basis. General Assembly Resolution A/RES/31/174 . Режим доступа: https://undocs.org/en/A/RES/31/174 (дата обращения: 14.08.2018).

United Nations (UN) (1976d) Establishment of the United Nations (UN) Industrial Development Fund. General Assembly Resolution A/RES/31/202. Режим доступа: https://undocs.org/en/A/RES/31/202 (дата обращения: 14.08.2018).

United Nations (UN) (1977a) Effects of the World Inflationary Phenomenon on the Development Process. General Assembly Resolution A/RES/32/175. Режим доступа: https://undocs.org/en/A/RES/32/175 (дата обращения: 14.08.2018). 
United Nations (UN) (1977b) Debt Problems of Developing Countries. General Assembly Resolution A/ RES/32/187. Режим доступа: https://undocs.org/en/A/RES/32/187 (дата обращения: 14.08.2018).

United Nations (UN) (1977c) United Nations (UN) Conference on the Establishment of the United Nations (UN) Industrial Development Organization as a Specialized Agency. General Assembly Resolution A/ RES/32/167. Режим доступа: https://undocs.org/en/A/RES/32/167 (дата обращения: 14.08.2018).

United Nations (UN) (1977d) Strengthening of Operational Activities in the Field of Industrial Development. General Assembly Resolution A/RES/32/165. Режим доступа: https://undocs.org/en/A/RES/32/165 (дата обращения: 14.08.2018).

United Nations (UN) (1977e) Target for World Food Programme Pledges for the Period 1979-1980. General Assembly Resolution A/RES/32/112. Режим доступа: https://undocs.org/en/A/RES/32/112 (дата обращения: 14.08.2018).

United Nations (UN) (1978a) Multilateral Trade Negotiations (110-11-11). General Assembly Resolution A/ RES/33/199. Режим доступа: https://undocs.org/en/A/RES/33/199 (дата обращения: 14.08.2018).

United Nations (UN) (1978b) Protectionism (109-1-24). General Assembly Resolution A/RES/33/196. Режим доступа: https://undocs.org/en/A/RES/33/196 (дата обращения: 14.08.2018).

United Nations (UN) (1978c) Industrial Development Cooperation. General Assembly Resolution A/ RES/33/78. Режим доступа: https://undocs.org/en/A/RES/33/78 (дата обращения: 14.08.2018).

United Nations (UN) (1978d) Preparations for an International Development Strategy for the Third United Nations (UN) Development Decade. General Assembly Resolution A/RES/33/193. Режим доступа: https:// undocs.org/en/A/RES/33/193 (дата обращения: 14.08.2018).

United Nations (UN) (1979a) United Nations (UN) Conference on Science and Technology for Development. General Assembly Resolution A/RES/34/218. Режим доступа: https://undocs.org/en/A/RES/34/218 (дата обращения: 14.08.2018).

United Nations (UN) (1979b) Proposals for the New International Development Strategy. General Assembly Resolution A/RES/34/211. Режим доступа: https://undocs.org/en/A/RES/34/211 (дата обращения: 14.08.2018).

United Nations (UN) (1979c) Official Records of the General Assembly, Thirty-Fourth Session. Режим доступа: https://undocs.org/en/A/34/PV.109 (дата обращения: 14.08.2018).

United Nations (UN) (1979d) Global Negotiations Relating to International Economic Cooperation for Development. General Assembly Resolution A/RES/34/138. Режим доступа: https://undocs.org/en/A/ RES/34/138 (дата обращения: 14.08.2018).

United Nations (UN) (1979e) Sixth Replenishment of the International Development Association and Recapitalization of the World Bank. General Assembly Resolution A/RES/34/208. Режим доступа: https://undocs. org/en/A/RES/34/208(дата обращения: 14.08.2018).

United Nations (UN) (1979f) International Monetary Reform. General Assembly Resolution A/RES/34/216. Режим доступа: https://undocs.org/en/A/RES/34/216 (дата обращения: 14.08.2018).

United Nations (UN) (1979g) Multilateral Trade Negotiations (112-1-22). General Assembly Resolution A/ RES/34/199. Режим доступа: https://undocs.org/en/A/RES/34/199 (дата обращения: 14.08.2018).

United Nations (UN) (1980a) International Development Strategy for the Third United Nations (UN) Development Decade. General Assembly Resolution A/RES/35/56. Режим доступа: https://undocs.org/en/A/ $\mathrm{RES} / 35 / 56$ (дата обращения: 14.08.2018).

United Nations (UN) (1980b) Official Records of the General Assembly, Thirty-Fifth Session. Режим доступа: https://undocs.org/en/A/35/PV.84 (дата обращения: 14.08.2018).

United Nations (UN) (1981a) United Nations (UN) Financing System for Science and Technology for Development. General Assembly Resolution A/RES/36/183. Режим доступа: https://undocs.org/en/A/ RES/36/183 (дата обращения: 14.08.2018).

United Nations (UN) (1981b) Industrial Development Cooperation. General Assembly Resolution A/ RES/36/182. Режим доступа: https://undocs.org/en/A/RES/36/182 (дата обращения: 14.08.2018).

United Nations (UN) (1981c) Global Strategy for Health for All by the Year 2000. General Assembly Resolution A/RES/36/43. Режим доступа: https://undocs.org/en/A/RES/36/43 (дата обращения: 14.08.2018). 
United Nations (UN) (1982a) Development of the Energy Resources of Developing Countries. General Assembly Resolution A/RES/37/251. Режим доступа: https://undocs.org/en/A/RES/37/251 (дата обращения: 14.08.2018).

United Nations (UN) (1982b) Negative Trends in the World Economy. General Assembly Resolution A/ RES/37/203. Режим доступа: https://undocs.org/en/A/RES/37/203 (дата обращения: 14.08.2018).

United Nations (UN) (1982c) Immediate Measures in Favour of the Developing Countries. General Assembly Resolution A/RES/37/252. Режим доступа: https://undocs.org/en/A/RES/37/252 (дата обращения: 14.08.2018).

United Nations (UN) (1982d) A/37/51/Add.1. Launching of Global Negotiations on International Economic Co-Operation for Development.

United Nations (UN) (1982e) Official Records of the General Assembly, Thirty-Seventh Session. Режим доступа: https://undocs.org/en/A/37/PV.122 (дата обращения: 14.08.2018).

United Nations (UN) (1982f) Review of the Implementation of the Charter of Economic Rights and Duties (144-1(США)-4). General Assembly Resolution A/RES/37/204. Режим доступа: https://undocs.org/en/A/ RES/37/204 (дата обращения: 14.08.2018).

United Nations (UN) (1983) Economic Measures as a Means of Political and Economic Coercion Against Developing Countries (119-19 (U.S. and Partners) -5). General Assembly Resolution A/RES/38/197. Режим доступа: https://undocs.org/en/A/RES/38/197 (дата обращения: 14.08.2018).

United Nations (UN) (1984) Relationship Between Disarmament and Development. General Assembly Resolution A/RES/39/160. Режим доступа: https://undocs.org/en/A/RES/39/160 (дата обращения: 14.08.2018).

United Nations (UN) (1984) Review of the Implementation of the Charter of Economic Rights and Duties - Review of the Implementation and Creation of a Special Review Committee (125-10 (U.S. +) - 12). General Assembly Resolution A/RES/39/163. Режим доступа: https://undocs.org/en/A/RES/39/163 (дата обращения: 14.08.2018).

United Nations (UN) (1984) Economic Measures as a Means of Political and Economic Coercion Against Developing Countries (116-19 (U.S. +) - 6). General Assembly Resolution A/RES/39/210. Режим доступа: https://undocs.org/en/A/RES/39/210 (дата обращения: 14.08.2018).

United Nations (UN) (1985) Review of the Implementation of the Charter of Economic Rights and Duties Review of the Implementation of the Charter at the 44th Session (134-1-19). General Assembly Resolution A/ RES/40/182. Режим доступа: https://undocs.org/en/A/RES/40/182 (дата обращения: 14.08.2018).

United Nations (UN) (1985) Economic Measures as a Means of Political and Economic Coercion Against Developing Countries (128-19-7). General Assembly Resolution A/RES/40/185. Режим доступа: https:// undocs.org/en/A/RES/40/185 (дата обращения: 14.08.2018).

United Nations (UN) (1986a) Strengthened International Economic Cooperation Aimed at Resolving External Debt Problems of Developing Countries. General Assembly Resolution A/RES/41/202. Режим доступа: https://undocs.org/en/A/RES/41/202 (дата обращения: 14.08.2018).

United Nations (UN) (1986b) Declaration on the Right to Development. General Assembly Resolution A/ RES/41/128. Режим доступа: https://undocs.org/en/A/RES/41/128 (дата обращения: 14.08.2018).

United Nations (UN) (1986c) Economic Measures as a Means of Political and Economic Coercion Against Developing Countries (115-23-3). General Assembly Resolution A/RES/41/165. Режим доступа: https://undocs.org/en/A/RES/41/165 (дата обращения: 14.08.2018).

United Nations (UN) (1987a) Furthering International Cooperation Regarding the External Debt Problems. General Assembly Resolution A/RES/42/198. Режим доступа: https://undocs.org/en/A/RES/42/198 (дата обращения: 14.08.2018).

United Nations (UN) (1987b) Economic Measures as a Means of Political and Economic Coercion Against Developing Countries (128-21-5). General Assembly Resolution A/RES/42/173. Режим доступа: https://undocs.org/en/A/RES/42/173 (дата обращения: 14.08.2018).

United Nations (UN) (1987c) Relationship Between Disarmament and Development. General Assembly Resolution A/RES/4245. Режим доступа: https://undocs.org/en/A/RES/42/45 (дата обращения: 14.08.2018).

United Nations (UN) (1987d) Official Records of the General Assembly, Forty-Second Session. Preliminary Verbatim Report of the 85th Meeting. Режим доступа: https://undocs.org/en/A/42/PV.85 (дата обращения: 14.08.2018). 
United Nations (UN) (1987e) Report of the World Commission on Environment and Development. General Assembly Resolution A/RES/42/187. Режим доступа: https://undocs.org/en/A/RES/42/187 (дата обращения: 14.08.2018).

United Nations (UN) (1988a) External Debt Crisis and Development: Towards a Durable Solution of the Debt Problems. General Assembly Resolution A/RES/43/198. Режим доступа: https://undocs.org/en/A/ RES/43/198 (дата обращения: 14.08.2018).

United Nations (UN) (1988b) Fulfilment of the Target for Official Development Assistance. General Assembly Resolution A/RES/43/197. Режим доступа: http://www.un.org/documents/ga/res/43/a43r197.htm (дата обращения: 14.08.2018).

United Nations (UN) (1988c) Relationship Between Disarmament and Development. General Assembly Resolution A/RES/43/75B. Режим доступа: https://undocs.org/en/A/RES/43/75 (дата обращения: 14.08.2018).

United Nations (UN) (1989a) Towards a Durable Solution of External Debt Problems. General Assembly Resolution A/RES/44/205. Режим доступа: https://undocs.org/en/A/RES/44/205 (дата обращения: 14.08.2018).

United Nations (UN) (1989b) Economic Measures as a Means of Political and Economic Coercion Against Developing Countries (118-23 (США+)-2). General Assembly Resolution A/RES/44/215. Режим доступа: https://undocs.org/en/A/RES/44/215 (дата обращения: 14.08.2018).

United Nations (UN) (1989c) Review of the Implementation of the Charter of Economic Rights and Duties On the Need to Implement the Charter (131-1-23). General Assembly Resolution A/RES/44/170. Режим доступа: https://undocs.org/en/A/RES/44/170 (дата обращения: 14.08.2018).

United Nations (UN) (1989d) Relationship Between Disarmament and Development. General Assembly Resolution A/RES/44/116L. Режим доступа: https://undocs.org/en/A/RES/44/116 (дата обращения: 14.08.2018).

United Nations (UN) (1989e) United Nations (UN) Conference on Environment and Development. General Assembly Resolution A/RES/44/228. Режим доступа: https://undocs.org/en/A/RES/44/228 (дата обращения: 14.08.2018).

United Nations (UN) (1990a) International Development Strategy for the Fourth United Nations (UN) Development Decade. General Assembly Resolution A/RES/45/199. Режим доступа: https://undocs.org/en/A/ RES/45/199 (дата обращения: 14.08.2018).

United Nations (UN) (1990b) International Debt Crisis and Development: Enhanced International Cooperation Towards a Durable Solution to the External Debt Problems of Developing Countries. General Assembly Resolution A/RES/45/214. Режим доступа: https://undocs.org/en/A/RES/45/214 (дата обращения: 14.08.2018).

United Nations (UN) (1991a) Impact of the Recent Evolution of East-West Relations on the Growth of the World Economy, in Particular on the Economic Growth and Development of the Developing Countries, As Well As on International Economic Cooperation. General Assembly Resolution A/RES/46/202. Режим доступа: https://undocs.org/en/A/RES/46/202 (дата обращения: 14.08.2018).

United Nations (UN) (1991b) International Debt Crisis and Development Enhanced International Cooperation Towards a Durable Solution to the External Debt Problems of Developing Countries. General Assembly Resolution A/RES/46/148. Режим доступа: https://undocs.org/en/A/RES/46/148 (дата обращения: 14.08.2018).

United Nations (UN) (1992a) Impact of the Recent Evolution of the Economies in Transition on the Growth of the World Economy, in Particular on the Economic Growth and Development of the Developing Countries, As Well As on International Economic Cooperation. General Assembly Resolution A/RES/47/175. Режим доступа: https://undocs.org/en/A/RES/47/175 (дата обращения: 14.08.2018).

United Nations (UN) (1992b) International Debt Crisis and Development Enhanced International Cooperation Towards a Durable Solution to the External Debt Problems of Developing Countries. General Assembly Resolution A/RES/47/198. Режим доступа: https://undocs.org/en/A/RES/47/198 (дата обращения: 14.08.2018).

United Nations (UN) (1992c) Development Agenda. General Assembly Resolution A/RES/47/181. Режим доступа: https://undocs.org/en/A/RES/47/181 (дата обращения: 14.08.2018). 
United Nations (UN) (1992d) Rio Declaration on Environment and Development A/CONF.151/26. United Nations Conference on Environment and Development. Режим доступа: http://www.un-documents.net/riodec.htm (дата обращения: 14.08.2018).

United Nations (UN) (1994) Enhanced International Cooperation Towards a Durable Solution to the External Debt Problems of Developing Countries. General Assembly Resolution A/RES/49/94. Режим доступа: https://undocs.org/en/A/RES/49/94 (дата обращения: 14.08.2018).

United Nations (UN) (1995a) Enhancing International Cooperation Towards a Durable Solution to the External Debt Problems of Developing Countries. General Assembly Resolution A/RES/50/92. Режим доступа: https://undocs.org/en/A/RES/50/92 (дата обращения: 14.08.2018).

United Nations (UN) (1995b) International Trade and Development. General Assembly Resolution A/ RES/50/95. Режим доступа: https://undocs.org/en/A/RES/50/95 (дата обращения: 14.08.2018).

United Nations (UN) (1996a) Global Financing Integration and Strengthening Collaboration Between the United Nations (UN) and the Bretton Woods Institutions. General Assembly Resolution A/RES/51/166. Режим доступа: https://undocs.org/en/A/RES/51/166 (дата обращения: 14.08.2018).

United Nations (UN) (1996b) Suppression of the Use of Economic Coercive Measures as a Means of Exerting Political and Economic Pressure (56-4 (Israel, Micronesia, Uzbekistan, and the U.S.) -76). General Assembly Resolution A/RES/51/22. Режим доступа: https://undocs.org/en/A/RES/51/22 (дата обращения: 14.08.2018).

United Nations (UN) (1997a) Unilateral Economic Measures as a Means of Political and Economic Coercion of Developing Countries (109-1 (U.S.) -50). General Assembly Resolution A/RES/52/181. Режим доступа: https://undocs.org/en/A/RES/53/10 (дата обращения: 14.08.2018).

United Nations (UN) (1997b) Global Financing Flows and Their Impact on the Developing Countries. General Assembly Resolution A/RES/52/180. Режим доступа: https://undocs.org/en/A/RES/52/180 (дата обращения: 14.08.2018).

United Nations (UN) (1997c) Agenda for Development. General Assembly Resolution A/RES/51/240. Режим доступа: https://undocs.org/en/A/RES/51/240 (дата обращения: 14.08.2018).

United Nations (UN) (1998a) Suppression of the Use of Economic Coercive Measures as a Means of Exerting Political and Economic Pressure (80-2 (U.S. and Israel) -67). General Assembly Resolution A/RES/53/10. Режим доступа: (дата обращения: 14.08.2018).

United Nations (UN) (1998b) the Financial Crisis and Its Impact on Growth and Development, Especially in the Developing Countries. General Assembly Resolution A/RES/53/172. Режим доступа: https://undocs. org/en/A/RES/53/172 (дата обращения: 14.08.2018).

United Nations (UN) (1998c) International Trade and Development. General Assembly Resolution A/ RES/53/170. Режим доступа: https://undocs.org/en/A/RES/53/170 (дата обращения: 14.08.2018).

United Nations (UN) (1999a) Unilateral Economic Measures as a Means of Political and Economic Coercion of Developing Countries (94-3-43). General Assembly Resolution A/RES/54/200. Режим доступа: https:// undocs.org/en/A/RES/54/200 (дата обращения: 14.08.2018).

United Nations (UN) (1999b) Official Records of the General Assembly, Fifty-Fourth Session. Режим доступа: https://undocs.org/en/A/54/PV.87 (дата обращения: 14.08.2018).

United Nations (UN) (2000a) Towards Strengthened and Stable International Financial Architecture Responsive to the Priorities of Growth and Development, Especially in Developing Countries, and to the Promotion of Economic and Social Equity. General Assembly Resolution A/RES/55/186. Режим доступа: https://undocs. org/en/A/RES/55/186 (дата обращения: 14.08.2018).

United Nations (UN) (2000b) Official Records of the General Assembly, Fifty-Fifth Session. Режим доступа: https://undocs.org/en/A/55/PV.87 (дата обращения: 14.08.2018).

United Nations (UN) (2000c) Implementation of the Commitments and Policies Agreed Upon in the Declaration on International Economic Cooperation, in Particular the Revitalization of Economic Growth and Development of the Developing Countries, and Implementation of the International Development Strategy for the Fourth United Nations (UN) Development Decade. General Assembly Resolution A/RES/55/190. Режим доступа: https://undocs.org/en/A/RES/55/190 (дата обращения: 14.08.2018).

United Nations (UN) (2000d) United Nations (UN) Millennium Declaration. General Assembly Resolution A/RES/55/2. Режим доступа: https://undocs.org/en/A/RES/55/2 (дата обращения: 14.08.2018). 